\title{
Triazole-oligomers by 1,3-dipolar cycloaddition
}

\author{
Alan R. Katritzky, ${ }^{a}{ }^{a}$ Sandeep K. Singh, ${ }^{a}$ Nabin K. Meher, ${ }^{a}$ Jacek Doskocz, ${ }^{a, b}$ \\ Kazuyuki Suzuki, ${ }^{a}$ Rong Jiang, ${ }^{a}$ Geoffroy L. Sommen, ${ }^{a}$ David A. Ciaramitaro, ${ }^{c}$ \\ and Peter J. Steel ${ }^{d}$ \\ ${ }^{a}$ Center for Heterocyclic Compounds, Department of Chemistry, University of Florida, \\ Gainesville, FL 32611-7200, USA \\ ${ }^{b}$ Department of Chemistry, Wroclaw University of Technology, Wyb. Wyspianskiego 27, 50-370 \\ Wroclaw, Poland \\ ${ }^{c}$ Naval Air Warfare Center, China Lake, CA 93555, USA \\ ${ }^{d}$ Department of Chemistry, University of Canterbury, Christchurch, New Zealand \\ E-mail: Katritzky@chem.ufl.edu
}

\begin{abstract}
A variety of triazole-oligomers have been prepared under microwave and conventional conditions from novel alkynes and azides.
\end{abstract}

Keywords: 1,3-Dipolar cycloaddition, microwaves, alkynes, azides, triazoles

\section{Introduction}

Triazole-oligomers prepared by 1,3-dipolar cycloadditions of azides to alkynes ${ }^{1}$ are new binder cure systems in the initial stage of development for high-energy explosive and propellant formulations. ${ }^{2}$ Structural features such as the length of chains between the triazole cross-links significantly impact the mechanical properties of the rubber matrices produced by the triazolecured polymers. Previous reports on the synthesis of oligomers with 1,2,3-triazole subunits include 1,3-dipolar cycloadditions of dialkynes and diazides, ${ }^{3 a, b}$ dialkynes and monoazides, ${ }^{3 c}$ diazides and monoalkynes, ${ }^{3 \mathrm{~d}}$ or tris-alkynes and diazides. ${ }^{3 \mathrm{e}}$

The kinetics of 1,3-dipolar cycloaddition can be controlled by selecting the appropriate functionalities on the alkyne and the azide; reactions are faster with electron-withdrawing substituents on the alkyne while their presence on the azide has the opposite effect. ${ }^{1 \mathrm{e}}$ Previously utilized activating substituents on the alkyne mainly include alkoxycarbonyl, ${ }^{4}$ carboxyl, acyl, cyano, aryl, haloalkyl, trimethylsilyl, phenylsulfonyl or phosphonate. ${ }^{5}$

We have studied 1,3-dipolar cycloadditions between a variety of organic azides and alkynes to develop strategies for low-temperature $\left(\sim 50{ }^{\circ} \mathrm{C}\right)$ synthesis of oligo-triazoles as binder 
linkages for new high-energy explosive and propellant ingredients possessing the best combination of strength, energy and insensitivity. The azides studied in the present work include mono-, bi-, tri-, tetra- and hexa- azides. Alkynes used in this study include ethyl propiolate, dipropiolates from polyethylene glycols, amido- substituted di-alkynes and trimethylsilyl substituted acetylene core. The 1,3-dipolar cycloadditions between these azides and alkynes were performed under thermal conditions or microwave irradiation.

\section{Results and Discussion}

Preparation of tri- and hexa-azide cores. Treatment of 1,3,5-benzenetricarboxylic acid (1) with a catalytic amount of $\mathrm{H}_{2} \mathrm{SO}_{4}$ in refluxing methanol gave trimethyl 1,3,5benzenetricarboxylate (2) in 99\% yield. Reduction of 2 with $\mathrm{LiAlH}_{4}$ gave 1,3,5tris(hydroxymethyl)benzene (3) in $80 \%$ yield. ${ }^{6}$ Further treatment of 3 with $\mathrm{HBr}$ gave the tribromide $4 a$ in $75 \%$ yield. The desired tri-azide core 5 a was obtained in $97 \%$ yield by the reaction of 4a with $\mathrm{NaN}_{3}$. Similar reaction of the commercially available tri-bromide $\mathbf{4 b}$ with $\mathrm{NaN}_{3}$ gave the tri-azide core $\mathbf{5 b}$ in $99 \%$ yield (Scheme 1).<smiles>O=C(O)CCCCOC(=O)c1cc(C(=O)O)cc(C(=O)O)c1</smiles>

1<smiles>COC(=O)c1cc(C(=O)OC)cc(C(=O)OC)c1</smiles>

2, $99 \%$

3, $80 \%$ $\downarrow \mathrm{HBr}$<smiles>[R]c1c(CN)c([R])c(CN)c([R])c1CN</smiles>

5a: $\mathrm{R}=\mathrm{H}, 97 \%$

5b: $\mathrm{R}=\mathrm{Me}, 99 \%$

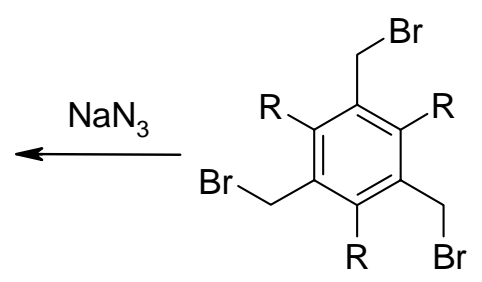

4a: $R=H, 75 \%$

4b: $\mathrm{R}=\mathrm{Me}$

\section{Scheme 1}

The hexa-azide core $\mathbf{6}$ was prepared by the reaction of $\mathbf{4 b}$ and 3,5-bis(azidomethyl)phenol 7, which was synthesized in four steps from commercially available 5-hydroxyisophthalic acid (8). Thus, methyl ester derivative 9 was obtained quantitatively by refluxing 8 in methanol in the presence of a catalytic amount of $\mathrm{H}_{2} \mathrm{SO}_{4}{ }^{6}$ Treatment of 9 with $\mathrm{LiAlH}_{4}$ provided 3,5- 
bishydroxymethylphenol (10) in $80 \%$ yield. Subsequent hydroxyl to bromine conversion using $\mathrm{HBr}$ gave the bis-bromo derivative 11 in 93\% yield; 11 was completely converted into 3,5bis(azidomethyl)phenol (7) using $\mathrm{NaN}_{3}$. The reaction of tribromide $\mathbf{4 b}$ ( 1 equiv) and bis-azide $\mathbf{7}$ ( 3 equiv) in the presence of $\mathrm{K}_{2} \mathrm{CO}_{3}$ furnished the desired hexa-azide core 6 in $79 \%$ yield (Scheme 2).<smiles>O=C(O)c1cc(O)cc(C(=O)O)c1</smiles>

8

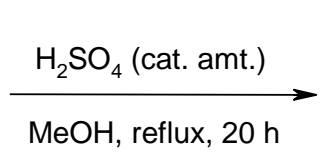

$\mathrm{MeOH}$, reflux, $20 \mathrm{~h}$<smiles>Cc1c(COc2cc(CN)cc(CN)c2)c(C)c(COc2cc(CN)cc(CN)c2)c(C)c1COc1cc(CN)cc(CN)c1</smiles>

6, $79 \%$<smiles>COC(=O)c1cc(O)cc(C(=O)OC)c1</smiles>

9, $100 \%$<smiles>NCc1cc(O)cc(CN)c1</smiles>

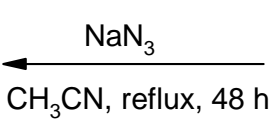<smiles>Oc1cc(CBr)cc(CBr)c1</smiles>

$7,99 \%$
$10,80 \%$ $\mathrm{HBr}, \mathrm{RT}$, $48 \mathrm{~h}$

$\checkmark$

$11,93 \%$

\section{Scheme 2}

Preparation of di-carboxyl azides. Reaction of dicarboxylic acid 12a,b with thionyl chloride and subsequent treatment of the acid chloride intermediate with sodium azide gave the dicarboxyl azides 13a,b following the literature method (Scheme 3). ${ }^{7}$ However, products 13a,b showed spontaneous decomposition when stored at room temperature; successful dipolar cycloaddition reactions could not be carried out.

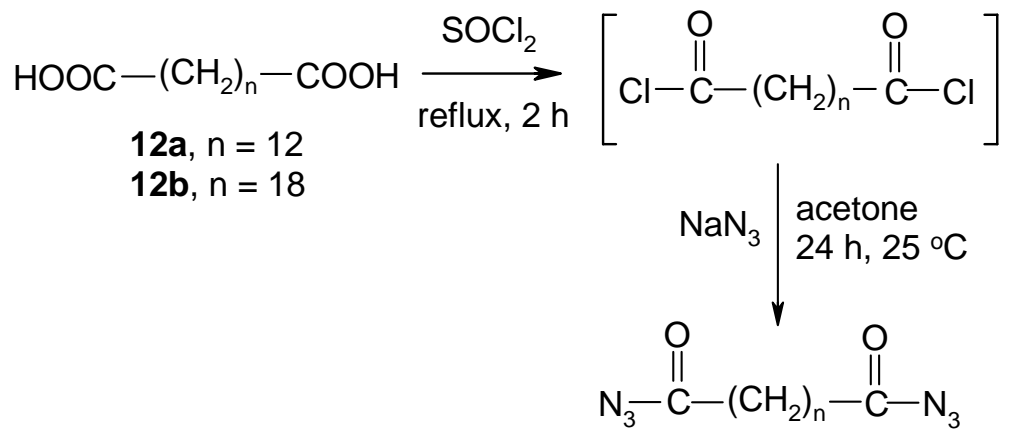

13a, $n=12$

$13 b, n=18$

\section{Scheme 3}


Preparation of oligoethyleneoxide di-azides. Reaction of oligoethylene glycol 14a with $\mathrm{TsCl}$ in the presence of $\mathrm{Ag}_{2} \mathrm{O}$, KI and $\mathrm{K}_{2} \mathrm{CO}_{3}$ gave the corresponding tosylate 15a in 55\% yield which was converted to the di-azide $\mathbf{1 6 a}$ using $\mathrm{NaN}_{3}$ in $91 \%$ yield. ${ }^{8}$ Similarly, starting from the oligoethyleneoxide glycol 14b and 14c, we prepared the tosylate 15b and 15c in 93 and 96\% yield respectively which on reaction with $\mathrm{NaN}_{3}$ gave the corresponding oligoethyleneoxide diazide 16b and 16c in 80 and $85 \%$ yield (Scheme 4).

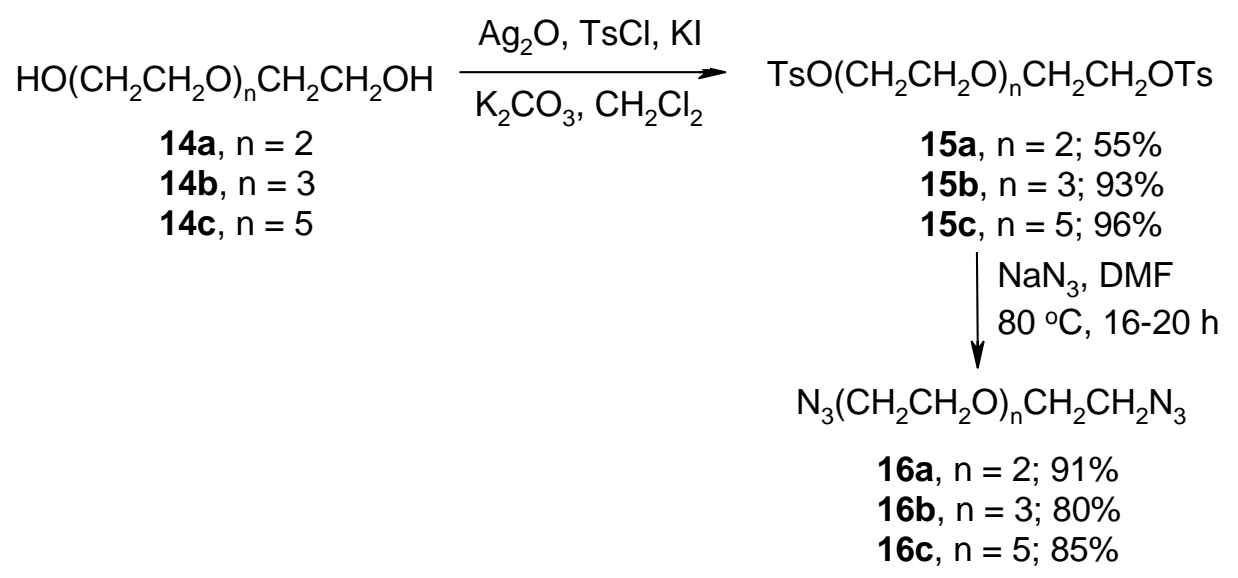

\section{Scheme 4}

Preparation of oligoethyleneoxide di-carboxylmethyl azide. The reaction of oligoethylene glycol 14c with chloroacetyl chloride ${ }^{9}$ gave the corresponding di-carboxylmethyl chloride 17c in $92 \%$ yield. Further reaction of $17 \mathrm{c}$ with sodium azide gave the desired di-carboxylmethyl azide 18c in 67\% yield. Similarly, from oligoethylene glycols 14b and 14d, di-carboxylmethyl azides 18b and 18d were prepared via chlorides $\mathbf{1 7 b}$ and 17d, respectively (Scheme 5).

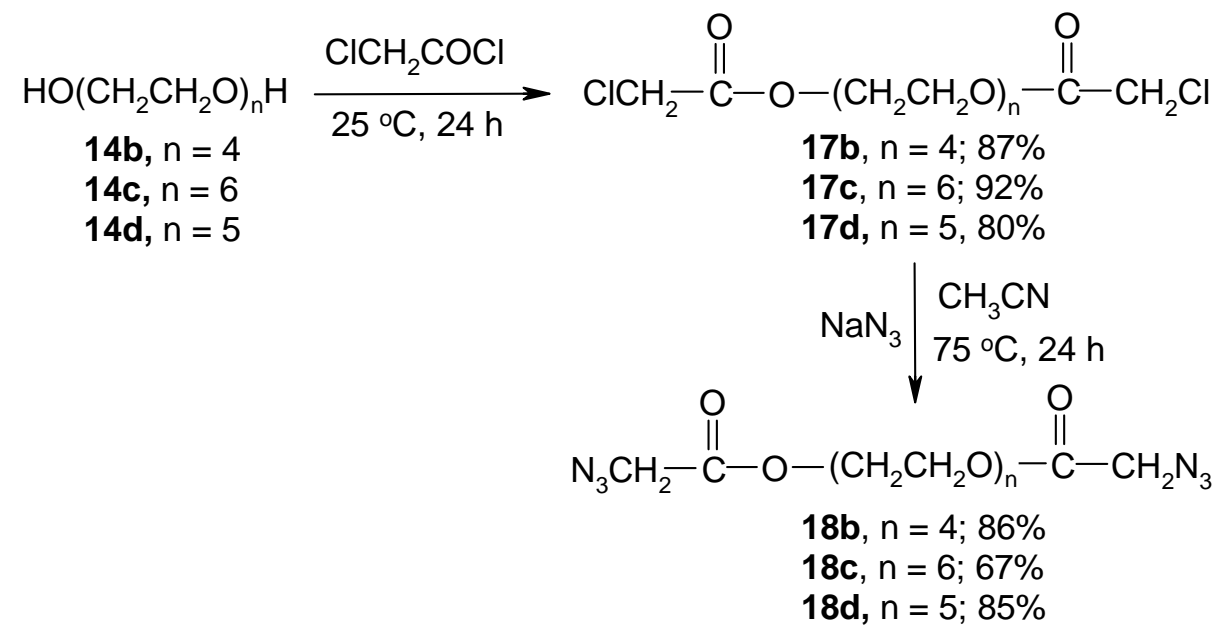

\section{Scheme 5}


Preparation of ortho- and para-substituted diazidopropanol derivatives. 1,3-Diazido-2propanol (19) was obtained in $76 \%$ yield by the reaction of epichlorohydrin and $\mathrm{NaN}_{3}$ in refluxing $\mathrm{CH}_{3} \mathrm{CN} / \mathrm{H}_{2} \mathrm{O}$ and was characterized by ${ }^{1} \mathrm{H}$ and ${ }^{13} \mathrm{C}$ NMR spectroscopy. Reaction of 19 with phthaloyl dichloride in pyridine gave the corresponding ortho-substituted diazidopropanol derivative 20 in $41 \%$ yield. Similar reaction of 19 with terephthaloyl dichloride gave the parasubstituted diazidopropanol derivative 21 in $70 \%$ yield (Scheme 6).

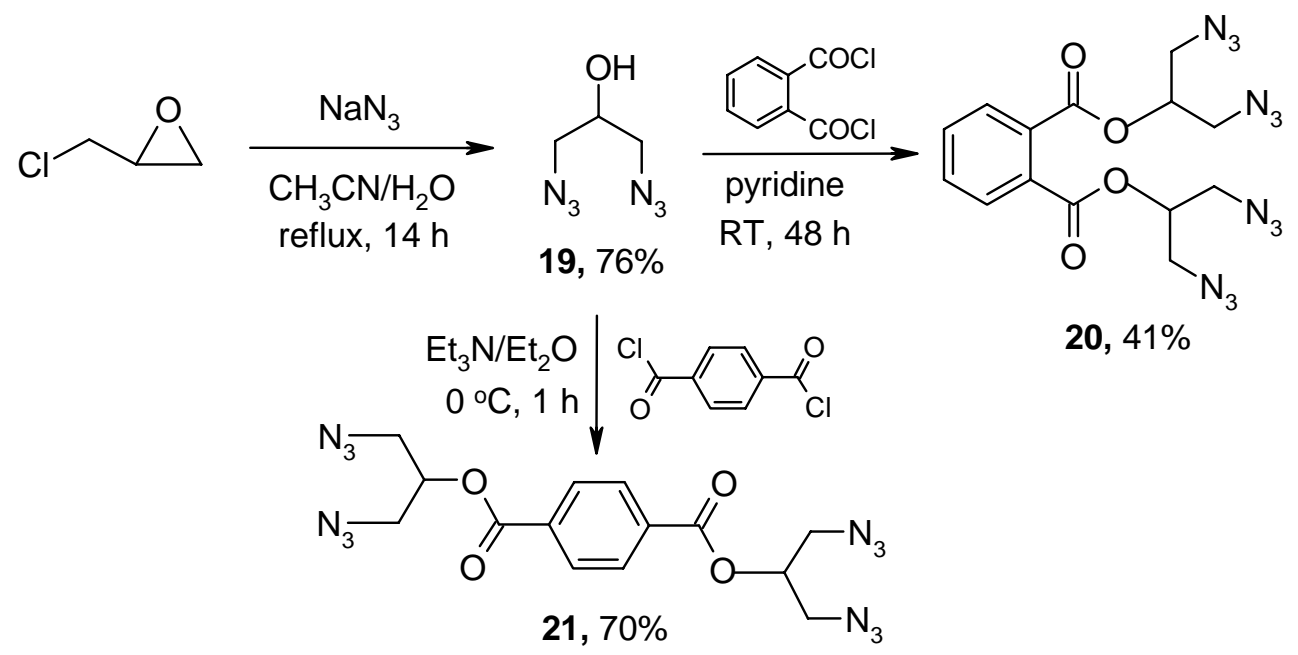

\section{Scheme 6}

Preparation of long-chain di-alkynes. The polyethylene glycol (E300) 22a was reacted with propiolic acid in the presence of a catalytic amount of $p-\mathrm{TsOH}$ in refluxing toluene to give the di-alkyne 23a in 98\% yield. ${ }^{10}$ Similar reactions of polyethylene glycols (E600) 22b and (E900) 22c with propiolic acid gave the corresponding di-alkynes 23b and 23c in 99 and 98\% yields, respectively (Scheme 7). E300, E600 and E900 are mixtures of polyethylene glycols, and their structures are most probable representatives based on average molecular weight.

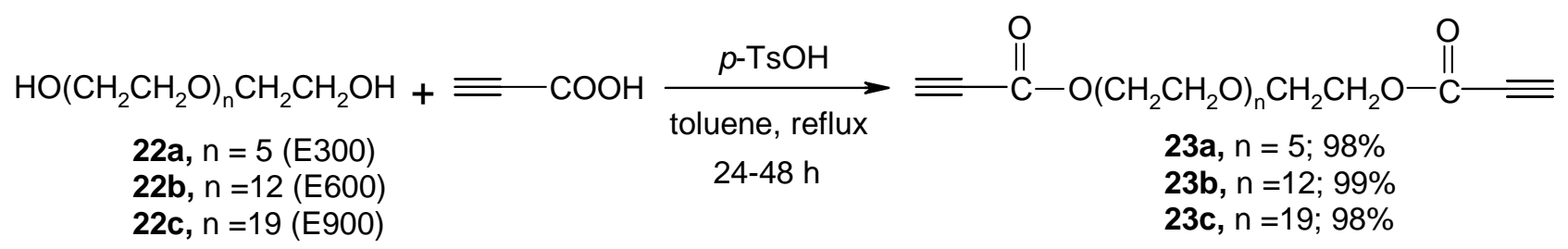

\section{Scheme 7}

Preparation of hydroxyl substituted di-acetylene. Lithiation of ethyl propiolate with $n$-BuLi at $-78{ }^{\circ} \mathrm{C}$ and reaction of the carbanion with terephthalaldehyde gave the hydroxyl substituted dialkyne 24 in $85 \%$ yield (Scheme 8). 


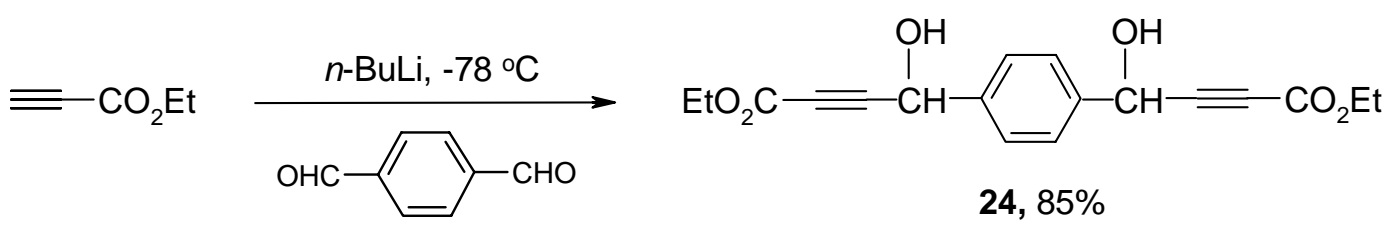

\section{Scheme 8}

Preparation of benzotriazolylcarbonyl acetylenes. Reactions of propiolic acid 25a or phenylpropiolic acid 25b with benzotriazole and thionyl chloride according to a recently developed procedure ${ }^{11}$ gave the corresponding benzotriazolylcarbonyl acetylenes 26a and 26b in $61 \%$ and $86 \%$ yields, respectively (Scheme 9 ).

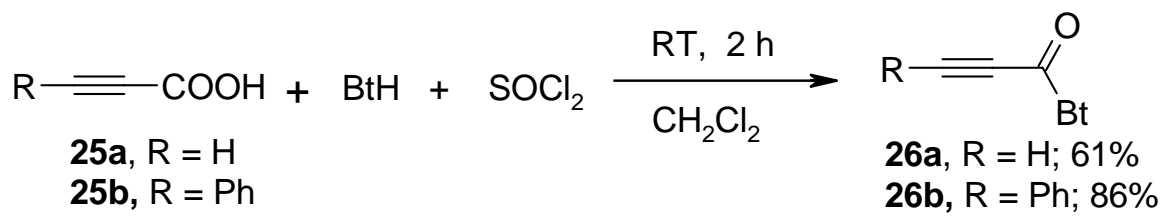

\section{Scheme 9}

Preparation of activated acetylene core. Trimethylsilyl- and triazene-substituted activated alkynes should undergo 1,3-dipolar cycloadditions with azides at low temperatures. We prepared the tris-alkyne $\mathbf{2 7}$ from trimethylsilyl acetylene and cyanuric fluoride according to a literature procedure. ${ }^{12}$ Thus, treatment of trimethylsilyl acetylene ( 3 equiv) with $n$-BuLi ( 3 equiv) at -78 ${ }^{\circ} \mathrm{C}$ in diethyl ether and subsequent reaction with cyanuric fluoride (1 equiv) in hexane gave the desired alkyne 27 in 50\% yield (Scheme 10).

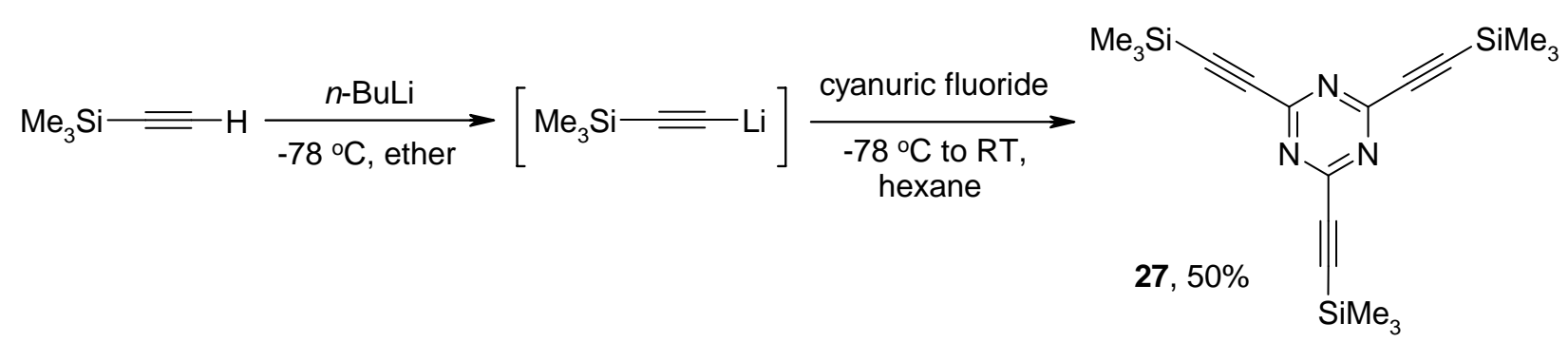

\section{Scheme 10}

Preparation of amido-substituted di-alkyne. Reaction of $N$-acylbenzotriazole derivative 26b with 1,8-diaminooctane gave the desired amido-substituted di-alkyne $\mathbf{2 8}$ in $88 \%$ yield as a white solid (Scheme 11). 


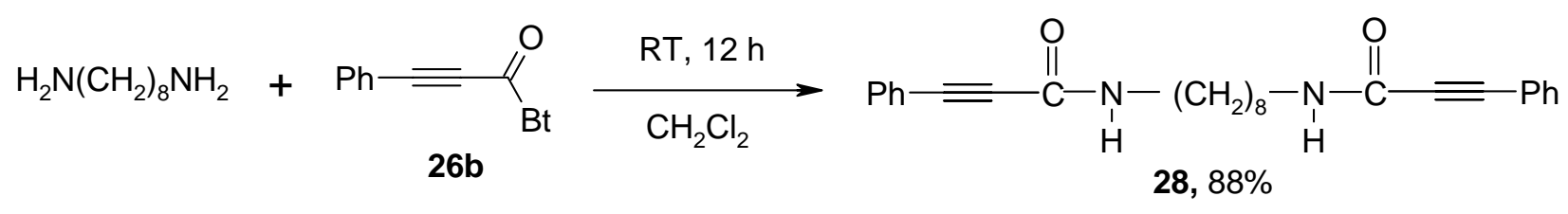

\section{Scheme 11}

Bistriazoles from long chain di-alkynes and benzyl azide. The mixture of di-alkyne 23a (1 equiv) and benzyl azide ( 2.5 equiv) was irradiated under microwaves at $120 \mathrm{~W}$ power and at 55 ${ }^{\circ} \mathrm{C}$ reaction temperature under solvent-free conditions for $1 \mathrm{~h}$. The ${ }^{1} \mathrm{H}$ NMR spectrum of the crude reaction mixture showed signals corresponding to the triazole proton at 8.01 and $8.17 \mathrm{ppm}$ and those from benzylic protons on the $\mathrm{N}$ atom of the triazole ring at 5.58 and $5.91 \mathrm{ppm}$. Further irradiation of the same reaction mixture at $120 \mathrm{~W}$ and $85{ }^{\circ} \mathrm{C}$ for $1 \mathrm{~h}$ resulted in complete reaction as indicated by disappearance of the acetylenic proton signal at $2.95-2.98 \mathrm{ppm}$. We also tried the above reaction under thermal conditions. Thus, 1 equiv of diacetylene 23a was mixed with 2.5 equiv of benzyl azide without any solvent and the resulting mixture was stirred for $2 \mathrm{~h}$ at 50-60 ${ }^{\circ} \mathrm{C}$ (oil bath temperature). The ${ }^{1} \mathrm{H}$ NMR spectrum of the reaction mixture indicated complete reaction, since the signals from acetylene 23a had disappeared to be replaced by the signals from triazole protons $(8.01$ and $8.17 \mathrm{ppm})$. The bistriazole 29 was formed in quantitative yield as a mixture of regioisomers in 1:3 ratio. Similar reaction of dialkynes $23 \mathbf{b}$ and $23 \mathbf{c}$ with benzyl azide gave the corresponding bis-triazoles 30 and 31 (Scheme 12).
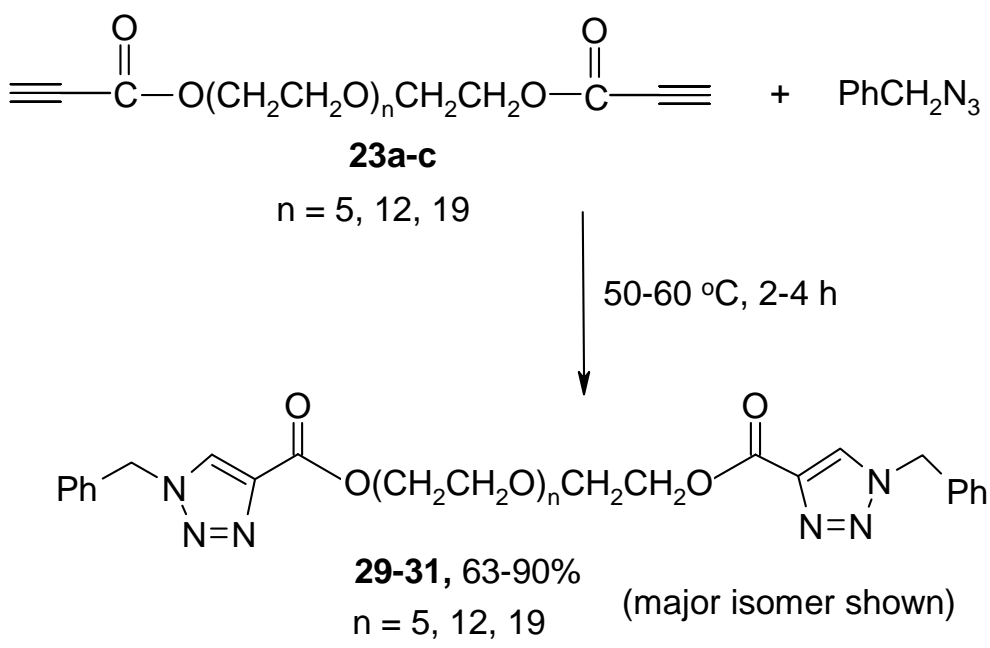

\section{Scheme 12}

Triazoles from ortho- and para-substituted diazidopropanol derivatives. Reaction of orthosubstituted diazidopropanol derivative 20 with ethyl propiolate (32) under solvent-free microwave irradiation at $50{ }^{\circ} \mathrm{C}$ and $60 \mathrm{~W}$ for $1 \mathrm{~h}$ gave a viscous material. TLC showed the presence of small amounts of starting materials. After repeated purification by column 
chromatography on silica-gel, the desired triazole 33 was obtained in $34 \%$ yield with $80 \%$ purity as indicated by ${ }^{1} \mathrm{H}$ NMR (Scheme 13).<smiles>N#CCC(CN)OC(=O)c1ccccc1C(=O)OC(CN)CN</smiles>

20

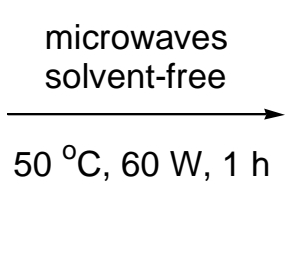

microwaves
solvent-free

$50^{\circ} \mathrm{C}, 60 \mathrm{~W}, 1 \mathrm{~h}$

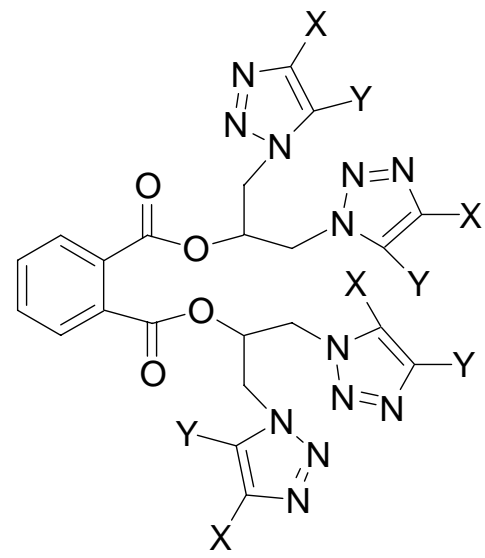

33, 34\% $\quad X, Y=H$ or $\mathrm{CO}_{2} \mathrm{Et}$

\section{Scheme 13}

Reaction of para-substituted diazidopropanol derivative 21 with ethyl propiolate (32) in toluene at $50{ }^{\circ} \mathrm{C}$ resulted in the formation of triazole 34 as a semi-solid that was recrystallised to give a white powder containing a mixture of six isomers (as indicated by TLC) in 91\% yield. After fractional recrystallization of this mixture, we isolated a single regioisomer 34a in $46 \%$ yield (Scheme 14).

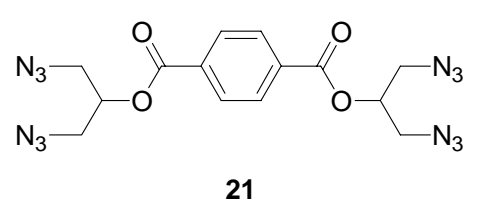

21

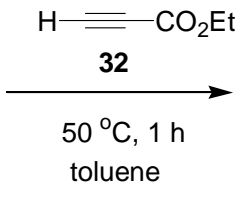

toluene

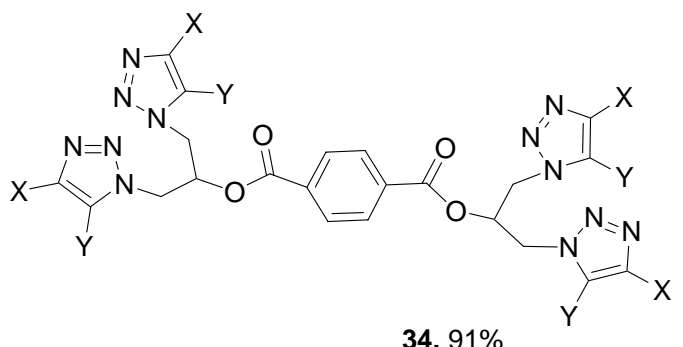

34, $91 \%$

mixture of regioisomers $\mathrm{X}, \mathrm{Y}=\mathrm{H}$ or $\mathrm{CO}_{2} \mathrm{Et}$

fractional recrystallization

single regioisomer $34 a$

mp $240-243{ }^{\circ} \mathrm{C}$

\section{Scheme 14}


Preparation of triazoles from amido-substituted dialkyne. Reaction of amido-substituted dialkyne 28 with benzyl azide in refluxing benzene for 3 days gave bis-triazole $\mathbf{3 5}$ as the major isomer in $46 \%$ yield (Scheme 15).

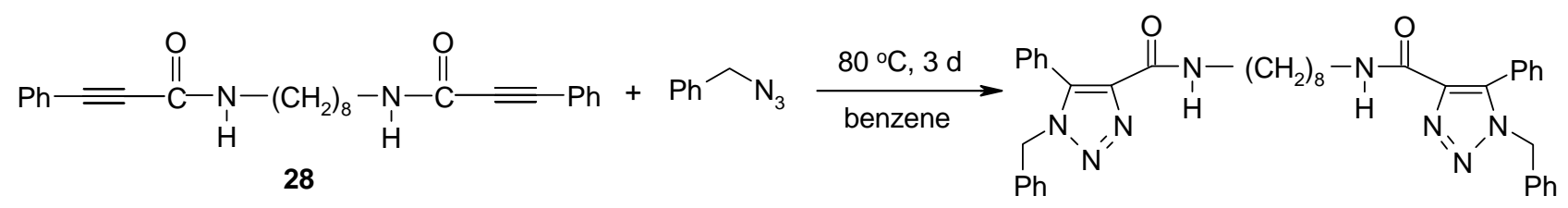

$35,46 \%$

\section{Scheme 15}

Triazole from activated acetylene core. We prepared tris-triazole 36 by the reaction of activated acetylene core 27 and benzyl azide at $50-60{ }^{\circ} \mathrm{C}$ for $8 \mathrm{~h}$. The crude material from the 1,3-dipolar cycloaddition reaction contained a mixture of regioisomeric triazoles, the major isomer 36 was separated in $45 \%$ yield by recrystallization (Scheme 16).

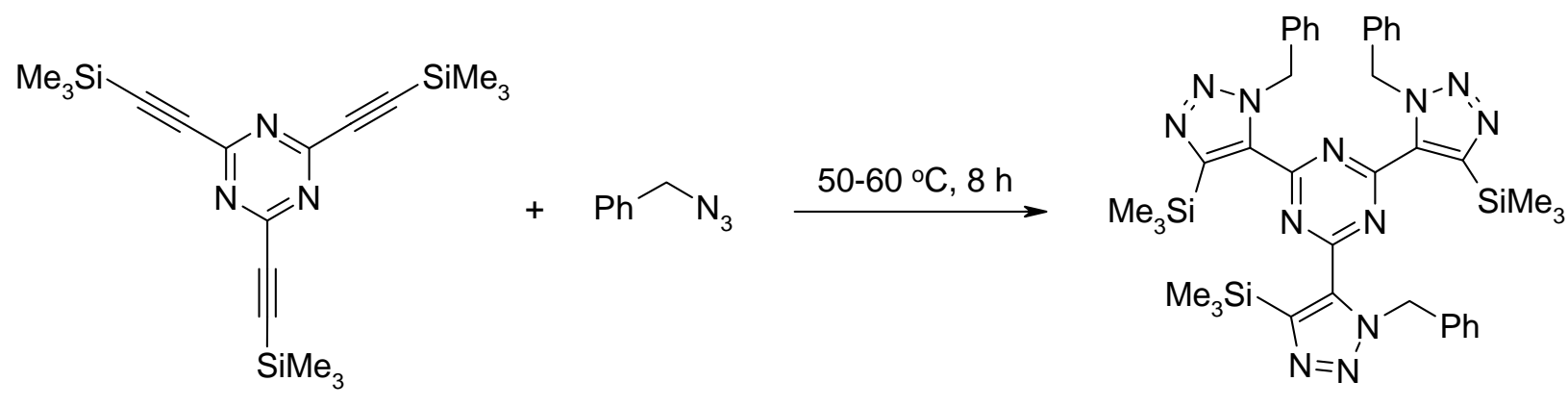

27

36, $45 \%$

\section{Scheme 16}

The structure of $\mathbf{3 6}$ was unambiguously established by single crystal X-ray crystallography (Figure 1), which confirmed the overall structure and the regiochemistry of the cycloaddition. In the solid state the molecule exists in a relatively compact conformation. The planes of the triazole rings are twisted relative to the plane of the central triazine ring at angles between 24.3 and $48.3^{\circ}$, with two of the benzyl substituents above the plane of the central ring and the other on the opposite side. 


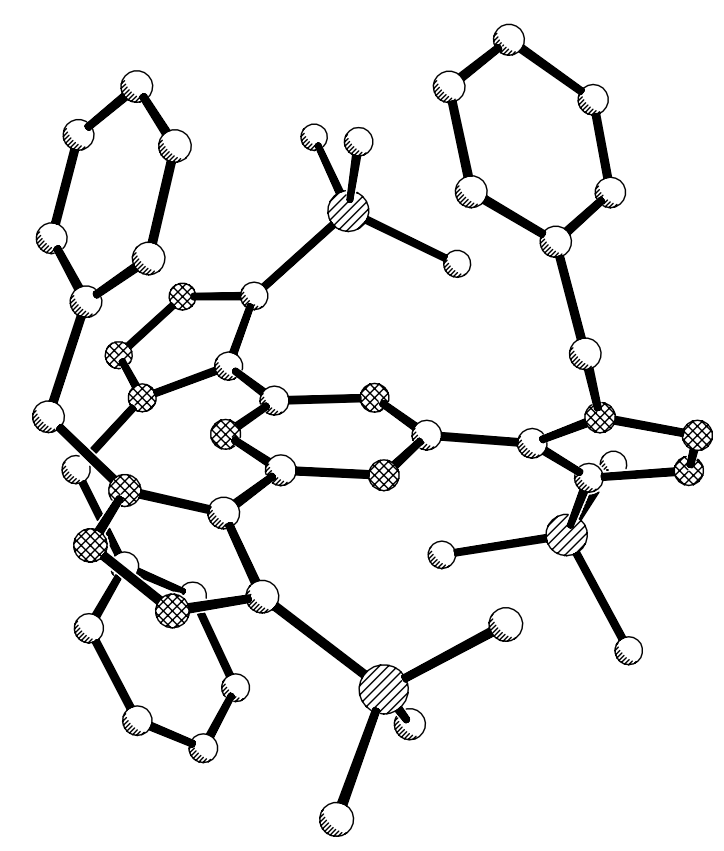

Figure 1. Perspective view of the X-ray crystal structure of 36. Hydrogen atoms have been omitted for clarity.

1,3-Dipolar cycloaddition reactions can be carried out employing other azides and alkynes substituted with carboxyl, acyl, cyano, arly, haloalkyl, phenylsulfonyl or phosphonate groups.

\section{Conclusions}

Various azides and alkyne compounds were prepared and their 1,3-dipolar cycloaddition reactions studied under microwave and conventional conditions. The main aim of the study was to complete the triazole formation at the lowest possible temperature. It has been found that the cycloaddition reactions of azides with alkynes substituted with electron-withdrawing groups are fast and take place at low temperatures $\left(\sim 50{ }^{\circ} \mathrm{C}\right)$, under microwave or conventional conditions.

\section{Experimental Section}

General Procedures. Melting points are uncorrected. ${ }^{1} \mathrm{H}$ and ${ }^{13} \mathrm{C}$ NMR spectra were recorded at 300 and $75 \mathrm{MHz}$, respectively, with tetramethylsilane (TMS) as an internal standard. Solvents were distilled by standard methods. Reagents obtained commercially were used without further purification. 
1,3,5-Tris(bromomethyl)benzene (4a). To a solution of 1,3,5-tris(hydroxymethyl)benzene 3 $(1.68 \mathrm{~g}, 10 \mathrm{mmol})$ in acetic acid $(10 \mathrm{~mL}), \mathrm{HBr} 30 \%$ in acetic acid $(13.5 \mathrm{~g}, 50 \mathrm{mmol})$ was added. The mixture was stirred at room temperature for $48 \mathrm{~h}$ and extracted with ether $(3 \times 60 \mathrm{~mL})$. The combined ether extracts were washed with water, $5 \% \mathrm{Na}_{2} \mathrm{CO}_{3}$ and brine and dried over anhydrous $\mathrm{MgSO}_{4}$. Filtration and evaporation of the solvent gave 4a (75\%) as a brownish powder; mp 93-94 ${ }^{\circ} \mathrm{C}$ (lit. $\left.{ }^{13} \mathrm{mp} 94-95{ }^{\circ} \mathrm{C}\right) ;{ }^{1} \mathrm{H}$ NMR $\left(\mathrm{CDCl}_{3}\right) \delta 4.45$ (s, 6H), $7.35(\mathrm{~s}, 3 \mathrm{H}) ;{ }^{13} \mathrm{C}$ NMR $\left(\mathrm{CDCl}_{3}\right) \delta 32.2,129.5,139.0$.

General procedure for triazides (5). A mixture of tris-bromomethyl compound 4 (1 mmol) and sodium azide $(0.39 \mathrm{~g}, 6 \mathrm{mmol})$ in DMF $(10 \mathrm{~mL})$ was stirred at $60{ }^{\circ} \mathrm{C}$ for $24 \mathrm{~h}$. The reaction mixture was poured into water, and extracted with ether $(3 \times 30 \mathrm{~mL})$. The combined organic extracts were washed with water and brine and dried over anhydrous $\mathrm{MgSO}_{4}$. After filtration and evaporation of solvent, the corresponding tris-azidomethyl compounds $\mathbf{5 a}$, b were obtained.

1,3,5-Tris(azidomethyl)benzene (5a). $(97 \%)^{14 a}$ Pale yellow oil; ${ }^{1} \mathrm{H}$ NMR $\left(\mathrm{CDCl}_{3}\right) \delta 4.40$ (s, $6 \mathrm{H}), 7.25(\mathrm{~s}, 3 \mathrm{H}) ;{ }^{13} \mathrm{C} \mathrm{NMR}\left(\mathrm{CDCl}_{3}\right) \delta 54.3,127.5$, 137.0. Anal. Calcd for $\mathrm{C}_{9} \mathrm{H}_{9} \mathrm{~N}_{9}: \mathrm{C}, 44.44 ; \mathrm{H}$, 3.73; N, 51.83. Found: C, 44.85; H, 3.79; N, 51.43.

1,3,5-Tris(azidomethyl)-2,4,6-trimethyl-benzene (5b). (99\%) White needles (from hexane); mp 64-65 ${ }^{\circ} \mathrm{C}$, previously reported ${ }^{14 \mathrm{~b}}$ without mp; ${ }^{1} \mathrm{H} \mathrm{NMR}\left(\mathrm{CDCl}_{3}\right) \delta 2.45(\mathrm{~s}, 9 \mathrm{H}), 4.49(\mathrm{~s}, 6 \mathrm{H})$; ${ }^{13} \mathrm{C}$ NMR $\left(\mathrm{CDCl}_{3}\right) \delta 16.4,48.9,130.8,138.1$. Anal. Calcd for $\mathrm{C}_{12} \mathrm{H}_{15} \mathrm{~N}_{9}: \mathrm{C}, 50.52 ; \mathrm{H}, 5.30 ; \mathrm{N}$, 44.18. Found: C, 50.86; H, 5.26; N, 43.95.

1,3,5-Tris $\{[3,5$-bis(azidomethyl)phenoxy]methyl\}-2,4,6-trimethylbenzene (6). A mixture of 3,5-bis(azidomethyl)phenol $7(0.27 \mathrm{~g}, 1.32 \mathrm{mmol})$ and 1,3,5-trisbromomethyl-2,4,6-trimethylbenzene 4b (0.176 g, $0.44 \mathrm{mmol})$ in DMF (5 mL) was stirred with $\mathrm{K}_{2} \mathrm{CO}_{3}(0.182 \mathrm{~g}, 1.32 \mathrm{mmol})$ for 2 days. The reaction mixture was poured into water and extracted with ethyl acetate $(3 \times 30$ $\mathrm{mL}$ ). The combined organic extracts was washed with water and brine and dried over anhydrous $\mathrm{MgSO}_{4}$. Filtration and evaporation of solvents followed by recrystallization (from hexane/chloroform), gave $6(0.26 \mathrm{~g}, 79 \%)$ as white microcrystals, $\mathrm{mp} 129-131{ }^{\circ} \mathrm{C}$, previously reported $^{14 \mathrm{~b}}$ without mp; ${ }^{1} \mathrm{H} \mathrm{NMR}\left(\mathrm{CDCl}_{3}\right) \delta 2.46(\mathrm{~s}, 9 \mathrm{H}), 4.37(\mathrm{~s}, 12 \mathrm{H}), 5.14(\mathrm{~s}, 6 \mathrm{H}), 6.90(\mathrm{~s}$, $3 \mathrm{H}), 6.95(\mathrm{~s}, 6 \mathrm{H}) ;{ }^{13} \mathrm{C} \mathrm{NMR}\left(\mathrm{CDCl}_{3}\right) \delta 16.0,54.5,65.1,114.0,120.1,131.5,137.7,139.5,159.8$. Anal. Calcd for $\mathrm{C}_{36} \mathrm{H}_{36} \mathrm{~N}_{18} \mathrm{O}_{3}$ : C, 56.24; H, 4.72; N, 32.79 Found: C, 56.06; H, 4.65; N, 31.95 .

3,5-Bis(azidomethyl)phenol (7). 3,5-Bis(bromomethyl)phenol 11 (0.28 g, $1 \mathrm{mmol}$ ) and sodium azide $(0.26 \mathrm{~g}, 4 \mathrm{mmol})$ in acetonitrile $(10 \mathrm{~mL})$ were stirred at $70{ }^{\circ} \mathrm{C}$ for $48 \mathrm{~h}$. The mixture was extracted with ethyl acetate, the organic extracts was washed with water, and dried over anhydrous $\mathrm{MgSO}_{4}$. Filtration and evaporation of the solvent gave 7 (99\%) as an oil; ${ }^{1} \mathrm{H} \mathrm{NMR}$ $\left(\mathrm{CDCl}_{3}\right) \delta 4.30(\mathrm{~s}, 4 \mathrm{H}), 5.03($ br s, $1 \mathrm{H}), 6.77(\mathrm{~s}, 2 \mathrm{H}), 6.83(\mathrm{~s}, 1 \mathrm{H}) ;{ }^{13} \mathrm{C} \mathrm{NMR}\left(\mathrm{CDCl}_{3}\right) \delta 54.2$, 114.9, 119.9, 137.8, 156.3. Anal. Calcd for $\mathrm{C}_{8} \mathrm{H}_{8} \mathrm{~N}_{6} \mathrm{O}: \mathrm{C}, 47.06 ; \mathrm{H}, 3.95 ; \mathrm{N}, 41.16$ Found: $\mathrm{C}$, 47.39; H, 3.93; N, 40.93. Previously reported ${ }^{14 \mathrm{~b}}$ without characterization.

Dimethyl 5-hydroxyisophthalate (9). (100\%) Colorless needles (from hexane/ethyl acetate); mp 160-162 ${ }^{\circ} \mathrm{C}$ (lit. ${ }^{15} \mathrm{mp} 165{ }^{\circ} \mathrm{C}$ ); ${ }^{1} \mathrm{H}$ NMR (DMSO-d 6 ) $\delta 3.85(\mathrm{~s}, 6 \mathrm{H}), 7.53-7.55(\mathrm{~m}, 2 \mathrm{H}), 7.92$ $(\mathrm{s}, 1 \mathrm{H}), 10.32$ (br s, $1 \mathrm{H}) ;{ }^{13} \mathrm{C}$ NMR (DMSO- $\left.d_{6}\right) \delta 52.4,120.2,120.3,131.4,157.9,165.4$. 
3,5-Bis(hydroxymethyl)phenol (10). A solution of dimethyl 5-hydroxyisophthalate 9 (3.0 g, $14.3 \mathrm{mmol})$ in dry THF $(15 \mathrm{~mL})$ was added slowly to a stirred suspension of $\mathrm{LiAlH}_{4}(1.0 \mathrm{~g}, 26.3$ $\mathrm{mmol})$ in THF $(50 \mathrm{~mL})$. The reaction was stirred under reflux for $3 \mathrm{~h}$ before being left to cool. The mixture was acidified by the addition of $10 \% \mathrm{H}_{2} \mathrm{SO}_{4}(20 \mathrm{~mL})$, and THF was removed under vacuum. The resulting solution was extracted with ethyl acetate and the combined extract was dried over anhydrous $\mathrm{MgSO}_{4}$. Filtration and evaporation of the solvent gave $10(80 \%)$ as a white solid; mp 73-74 ${ }^{\circ} \mathrm{C}$ (lit. ${ }^{6} \mathrm{mp} 73-74{ }^{\circ} \mathrm{C}$ ); ${ }^{1} \mathrm{H}$ NMR (DMSO-d $) \delta 4.40$ (s, 4H), 4.70 (br s, 1H), $6.60(\mathrm{~s}, 2 \mathrm{H}), 6.68(\mathrm{~s}, 1 \mathrm{H}) ;{ }^{13} \mathrm{C}$ NMR $\left(\mathrm{DMSO}_{-} \mathrm{d}_{6}\right) \delta 63.1,111.8,115.2,143.9,157.3$.

3,5-Bis(bromomethyl)phenol (11). To a solution of 3,5-bis(hydroxymethyl)phenol 10 (0.26 g, $1.68 \mathrm{mmol})$ in acetic acid $(2 \mathrm{~mL})$, hydrobromic acid $30 \%$ in acetic acid $(2.0 \mathrm{~mL}, 7 \mathrm{mmol})$ was added, and stirred for $48 \mathrm{~h}$. The reaction mixture was diluted with water $(10 \mathrm{~mL})$ and stirred for $10 \mathrm{~min}$. It was extracted with ether $(3 \times 30 \mathrm{~mL})$, the combined ether extract was washed with water $(2 \times 15 \mathrm{~mL})$, saturated $\mathrm{NaHCO}_{3}(2 \times 15 \mathrm{~mL})$ and brine $(10 \mathrm{~mL})$ and dried over anhydrous $\mathrm{MgSO}_{4}$. After filtration and evaporation of solvent followed by recrystallization (from diethyl ether/hexanes), 11 (0.44 g, 93\%) was obtained as colorless needles, mp 82-84 ${ }^{\circ} \mathrm{C}$, previously reported ${ }^{16}$ without mp; ${ }^{1} \mathrm{H} \mathrm{NMR}\left(\mathrm{CDCl}_{3}\right) \delta 4.41(\mathrm{~s}, 4 \mathrm{H}), 4.85$ (br s, 1H), $6.81(\mathrm{~s}, 2 \mathrm{H}), 6.99$ (s, $1 \mathrm{H}) ;{ }^{13} \mathrm{C} \mathrm{NMR}\left(\mathrm{CDCl}_{3}\right) \delta 32.5,116.1,122.1,139.9,155.7$. Anal. Calcd for $\mathrm{C}_{8} \mathrm{H}_{8} \mathrm{Br}_{2} \mathrm{O}: \mathrm{C}, 34.32$; H, 2.88. Found: C, 34.41; H, 2.68 .

General method for the preparation of ditosylates (15). A mixture of glycol 14 (10 mmol), $p$ toluenesulfonyl chloride (4.19 g, $22 \mathrm{mmol}), \mathrm{Ag}_{2} \mathrm{O}$ (6.95 g, $\left.30 \mathrm{mmol}\right), \mathrm{KI}(0.66 \mathrm{~g}, 4 \mathrm{mmol})$ and $\mathrm{K}_{2} \mathrm{CO}_{3}(3.0 \mathrm{~g}, 22 \mathrm{mmol})$ in $\mathrm{CH}_{2} \mathrm{Cl}_{2}(100 \mathrm{~mL})$ was heated under reflux with stirring for $24-48 \mathrm{~h}$. It was cooled to room temperature and the solid was filtered and washed with $\mathrm{CH}_{2} \mathrm{Cl}_{2}$. The solvent was removed under vacuum to afford the corresponding ditosylates 15a-c.

2-[2-(2-\{[(4-Methylphenyl)sulfonyl]oxy\}ethoxy)ethoxy]ethyl 4-methylbenzenesulfonate (15a). (55\%) Colorless plates (from hexane $/ \mathrm{CH}_{2} \mathrm{Cl}_{2}$ ); mp $79-80{ }^{\circ} \mathrm{C}$ (lit. ${ }^{17} \mathrm{mp} 80-81{ }^{\circ} \mathrm{C}$ ); ${ }^{1} \mathrm{H}$ NMR $\left(\mathrm{CDCl}_{3}\right) \delta 2.45(\mathrm{~s}, 6 \mathrm{H}), 3.53(\mathrm{~s}, 4 \mathrm{H}), 3.64-3.67(\mathrm{~m}, 4 \mathrm{H}), 4.12-4.15(\mathrm{~m}, 4 \mathrm{H}), 7.34(\mathrm{~d}, J=$ $8.4 \mathrm{~Hz}, 4 \mathrm{H}), 7.79(\mathrm{~d}, J=8.4 \mathrm{~Hz}, 4 \mathrm{H}) ;{ }^{13} \mathrm{C} \mathrm{NMR}\left(\mathrm{CDCl}_{3}\right) \delta 21.9,68.9,69.4,70.9,128.2,130.1$, $133.1,145.1$.

2-\{2-[2-(2-\{[(4-Methylphenyl)sulfonyl]oxy\}ethoxy)ethoxy]ethoxy\}ethyl 4-methylbenzene sulfonate (15b). ${ }^{17}$ (93\%) Colorless oil; ${ }^{1} \mathrm{H} \mathrm{NMR}\left(\mathrm{CDCl}_{3}\right) \delta 2.44(\mathrm{~s}, 6 \mathrm{H}), 3.56-3.60(\mathrm{~m}, 8 \mathrm{H})$, 3.66-3.69 (m, 4H), 4.14-4.17 (m, 4H), 7.34 (d, $J=7.8 \mathrm{~Hz}, 4 \mathrm{H}), 7.79(\mathrm{~d}, J=7.8 \mathrm{~Hz}, 4 \mathrm{H}) ;{ }^{13} \mathrm{C}$ NMR $\left(\mathrm{CDCl}_{3}\right) \delta 21.8,68.9,69.4,70.7,70.9,128.2,130.0,133.2,145.0$. Anal. Calcd for $\mathrm{C}_{22} \mathrm{H}_{30} \mathrm{O}_{9} \mathrm{~S}_{2}$ : C, 52.57; H, 6.02. Found: C, 52.64; H, 6.18.

17-\{[(4-Methylphenyl)sulfonyl]oxy\}-3,6,9,12,15-pentaoxaheptadec-1-yl methylbenzenesulfonate (15c). ${ }^{18}$ (96\%) Colorless oil; ${ }^{1} \mathrm{H}$ NMR $\left(\mathrm{CDCl}_{3}\right) \delta 2.45(\mathrm{~s}, 6 \mathrm{H}), 3.58-$ $3.62(\mathrm{~m}, 16 \mathrm{H}), 3.67-3.70(\mathrm{~m}, 4 \mathrm{H}), 4.14-4.17(\mathrm{~m}, 4 \mathrm{H}), 7.34(\mathrm{~d}, J=8.1 \mathrm{~Hz}, 4 \mathrm{H}), 7.80(\mathrm{~d}, J=8.1$ $\mathrm{Hz}, 4 \mathrm{H}) ;{ }^{13} \mathrm{C} \mathrm{NMR}\left(\mathrm{CDCl}_{3}\right) \delta 21.8,68.8,69.4,70.6,70.7,70.7,70.8,128.1,130.0,133.1,145.0$.

General method for the preparation of diazides (16). A mixture of ditosylate 15 (2 mmol) and $\mathrm{NaN}_{3}(0.52 \mathrm{~g}, 8 \mathrm{mmol})$ in DMF $(5 \mathrm{~mL})$ was heated at $80-90{ }^{\circ} \mathrm{C}$ with stirring for $16-20 \mathrm{~h}$. After cooling to room temperature water $(5 \mathrm{~mL})$ was added. The resultant solution was extracted with 
ethyl acetate $(3 \times 20 \mathrm{~mL})$ and the combined extract washed with water $(10 \mathrm{~mL})$ and brine $(20$ $\mathrm{mL}$ ). The organic layer was dried over anhydrous $\mathrm{Na}_{2} \mathrm{SO}_{4}$, filtered and the solvent evaporated under vacuum to afford the corresponding diazide $\mathbf{1 6 a}-\mathbf{c}$.

1-Azido-2-[2-(2-azidoethoxy)ethoxy]ethane (16a). ${ }^{19 a}(91 \%)$ Yellow oil; ${ }^{1} \mathrm{H}$ NMR $\left(\mathrm{CDCl}_{3}\right) \delta$ $3.38-3.41(\mathrm{~m}, 4 \mathrm{H}), 3.68-3.71(\mathrm{~m}, 8 \mathrm{H}) ;{ }^{13} \mathrm{C} \mathrm{NMR}\left(\mathrm{CDCl}_{3}\right) \delta 50.8,70.2,70.8$.

1-Azido-2-\{2-[2-(2-azidoethoxy)ethoxy]ethoxy\}ethane (16b). ${ }^{19 \mathrm{~b}}(80 \%)$ Colorless oil; ${ }^{1} \mathrm{H}$ NMR $\left(\mathrm{CDCl}_{3}\right) \delta 3.38-3.41(\mathrm{~m}, 4 \mathrm{H}), 3.67-3.70(\mathrm{~m}, 12 \mathrm{H}) ;{ }^{13} \mathrm{C} \mathrm{NMR}\left(\mathrm{CDCl}_{3}\right) \delta 50.9(2 \mathrm{C}), 70.2(2 \mathrm{C})$, 70.9 (4C).

1,17-Diazido-3,6,9,12,15-pentaoxaheptadecane (16c). (85\%) Colorless oil; ${ }^{1} \mathrm{H}$ NMR $\left(\mathrm{CDCl}_{3}\right) \delta$ 3.38-3.41 (m, 4H), 3.67-3.70 (m, 20H); ${ }^{13} \mathrm{C} \mathrm{NMR}\left(\mathrm{CDCl}_{3}\right) \delta 50.8,70.2,70.7,70.8,70.8,70.8$. Anal. Calcd for $\mathrm{C}_{12} \mathrm{H}_{24} \mathrm{~N}_{6} \mathrm{O}_{5}$ : C, 43.37; H, 7.28; N, 25.29 Found: C, 43.75; H, 7.45; N, 24.96. Previously reported ${ }^{20}$ without characterization.

General method for the preparation of di-chloroacetates (17). Chloroacetyl chloride (7.08 mmol) was added very slowly to a solution of glycol $14(3.54 \mathrm{mmol})$ and triethylamine $(1.0 \mathrm{~mL}$, $7.08 \mathrm{mmol})$ in dichloromethane $(30 \mathrm{~mL})$ at $0{ }^{\circ} \mathrm{C}$ in an ice bath. This mixture was then stirred at room temperature for $2 \mathrm{~h}$ before quenching with water $(50 \mathrm{~mL})$. The organic layer was separated, washed with aqueous $\mathrm{NaHCO}_{3} 5 \%(2 \times 50 \mathrm{~mL})$, brine $(30 \mathrm{~mL})$ and water $(30 \mathrm{~mL})$. The combined organic extracts were dried over $\mathrm{MgSO}_{4}$, filtered and evaporated under reduced pressure to give the corresponding di-chloroacetate $\mathbf{1 7} \mathbf{b}-\mathbf{d}$.

14-Chloro-13-oxo-3,6,9,12-tetraoxatetradec-1-yl 2-chloroacetate (17b). ${ }^{21}$ (87\%) Colorless oil; ${ }^{1} \mathrm{H}$ NMR $\left(\mathrm{CDCl}_{3}\right) \delta 3.66(\mathrm{~s}, 8 \mathrm{H}), 3.72-3.75(\mathrm{~m}, 4 \mathrm{H}), 4.11(\mathrm{~s}, 4 \mathrm{H}), 4.38-4.37(\mathrm{~m}, 4 \mathrm{H}) ;{ }^{13} \mathrm{C} \mathrm{NMR}$ $\left(\mathrm{CDCl}_{3}\right) \delta 40.8,65.1,68.7,70.5,70.6$, 167.3. Anal. Calcd for $\mathrm{C}_{12} \mathrm{H}_{20} \mathrm{Cl}_{2} \mathrm{O}_{7}: \mathrm{C}, 41.51 ; \mathrm{H}, 5.81$. Found: C, 41.40; H, 5.84 .

20-Chloro-19-oxo-3,6,9,12,15,18-hexaoxaicos-1-yl 2-chloracetate (17c). (92\%). Yellow oil; ${ }^{1} \mathrm{H}$ NMR $\left(\mathrm{CDCl}_{3}\right) \delta 3.65(\mathrm{~s}, 16 \mathrm{H}), 3.72-3.75(\mathrm{~m}, 4 \mathrm{H}), 4.12(\mathrm{~s}, 4 \mathrm{H}), 4.33-4.36(\mathrm{~m}, 4 \mathrm{H}) ;{ }^{13} \mathrm{C}$ NMR $\left(\mathrm{CDCl}_{3}\right) \delta 40.9,65.2,68.7,70.5,70.6,167.3$. Anal. Calcd for $\mathrm{C}_{16} \mathrm{H}_{28} \mathrm{Cl}_{2} \mathrm{O}_{9}: \mathrm{C}, 44.15 ; \mathrm{H}, 6.48$. Found: C, 43.99; H, 6.50 .

17-Chloro-16-oxo-3,6,9,12,15-pentaoxaheptadec-1-yl 2-chloroacetate (17d). (80\%) Colorless oil; ${ }^{1} \mathrm{H}$ NMR $\left(\mathrm{CDCl}_{3}\right) \delta 3.66(\mathrm{~s}, 12 \mathrm{H}), 3.72-3.75(\mathrm{~m}, 4 \mathrm{H}), 4.11(\mathrm{~s}, 4 \mathrm{H}), 4.33-4.37(\mathrm{~m}, 4 \mathrm{H}) ;{ }^{13} \mathrm{C}$ NMR $\left(\mathrm{CDCl}_{3}\right) \delta 40.9,65.2,68.8,70.6,70.7,167.4$. Anal. Calcd for $\mathrm{C}_{14} \mathrm{H}_{24} \mathrm{Cl}_{2} \mathrm{O}_{8}$ : C, 42.98; $\mathrm{H}$, 6.18. Found: C, 42.80; H, 6.50 .

14-Azido-13-oxo-3,6,9,12-tetraoxatetradec-1-yl 2-azidoacetate (18b). (86\%) Colorless oil; ${ }^{1} \mathrm{H}$ NMR $\left(\mathrm{CDCl}_{3}\right) \delta 3.66(\mathrm{~s}, 8 \mathrm{H}), 3.72-3.75(\mathrm{~m}, 4 \mathrm{H}), 3.92(\mathrm{~s}, 4 \mathrm{H}), 4.35-4.38(\mathrm{~m}, 4 \mathrm{H}) ;{ }^{13} \mathrm{C}$ NMR $\left(\mathrm{CDCl}_{3}\right) \delta 50.2,64.7,68.7,70.5,168.3$. Anal. Calcd for $\mathrm{C}_{12} \mathrm{H}_{20} \mathrm{~N}_{6} \mathrm{O}_{7}: \mathrm{C}, 40.00 ; \mathrm{H}, 5.59 ; \mathrm{N}$, 23.32. Found: C, 40.34; H, 5.63; N, 23.49 .

20-Azido-19-oxo-3,6,9,12,15,18-hexaoxaicos-1-yl 2-azidoacetate (18c). (67\%) Yellow oil; ${ }^{1} \mathrm{H}$ NMR $\left(\mathrm{CDCl}_{3}\right) \delta 3.64(\mathrm{~s}, 16 \mathrm{H}), 3.73-3.75(\mathrm{~m}, 4 \mathrm{H}), 3.93(\mathrm{~s}, 4 \mathrm{H}), 4.34-4.36(\mathrm{~m}, 4 \mathrm{H}) ;{ }^{13} \mathrm{C}$ NMR $\left(\mathrm{CDCl}_{3}\right) \delta 50.2,64.7,68.7,70.5,70.6,168.4$. Anal. Calcd for $\mathrm{C}_{16} \mathrm{H}_{28} \mathrm{~N}_{6} \mathrm{O}_{9}: \mathrm{C}, 42.85 ; \mathrm{H}, 6.29 ; \mathrm{N}$, 18.74. Found: C, 43.24; H, 6.40; N, 18.86 . 
17-Azido-16-oxo-3,6,9,12,15-pentaoxaheptadec-1-yl 2-azidoacetate (18d). (85\%) Colorless oil; ${ }^{1} \mathrm{H}$ NMR $\left(\mathrm{CDCl}_{3}\right) \delta 3.65(\mathrm{~s}, 12 \mathrm{H}), 3.72-3.75(\mathrm{~m}, 4 \mathrm{H}), 3.92(\mathrm{~s}, 4 \mathrm{H}), 4.34-4.37(\mathrm{~m}, 4 \mathrm{H}) ;{ }^{13} \mathrm{C}$ NMR $\left(\mathrm{CDCl}_{3}\right) \delta 50.0,64.5,68.6,70.3,70.4,168.2$. HRMS calcd for $\mathrm{C}_{14} \mathrm{H}_{25} \mathrm{~N}_{6} \mathrm{O}_{8}[\mathrm{M}+\mathrm{H}]^{+}$ 405.1728, found: 405.1733 .

1,3-Diazido-2-propanol (19). ${ }^{22}$ To a mixture of epichlorohydrin $(2.36$ g., $25.6 \mathrm{mmol})$ in acetonitrile $(30 \mathrm{~mL})$ and water $(15 \mathrm{~mL})$ was added sodium azide $(4 \mathrm{~g}, 61.5 \mathrm{mmol})$ and the resulting mixtire was heated under reflux overnight. The reaction mixture was then concentrated under vacuum to remove acetonitrile and the remaining aqueous suspension was extracted with methylene chloride $(2 \times 15 \mathrm{~mL})$. The organic extracts were combined, dried over anhydrous $\mathrm{Na}_{2} \mathrm{SO}_{4}$, filtered and the filtrate was concentrated under vacuum to obtain $19(2.79 \mathrm{~g}, 76 \%)$ as a light yellow oil; ${ }^{1} \mathrm{H}$ NMR $\left(\mathrm{CDCl}_{3}\right) \delta 2.64$ (br s, 1H), 3.36-3.46 (m, 4H), 3.90-3.97 (m, 1H); ${ }^{13} \mathrm{C}$ $\operatorname{NMR}\left(\mathrm{CDCl}_{3}\right) \delta 54.1,69.7$.

Bis[2-azido-1-(azidomethyl)ethyl] phthalate (20). ${ }^{23}$ To an ice cooled solution of $19(2.4 \mathrm{~g}, 16.9$ mmol) in pyridine $(20 \mathrm{~mL})$ was added phthaloyl dichloride $(2 \mathrm{~g}, 9.85 \mathrm{mmol})$ and the resulting mixture was stirred at room temperature for $48 \mathrm{~h}$. The reaction mixture was concentrated on a rotary evaporator to remove most of the pyridine and the residue was dissolved in methylene chloride $(100 \mathrm{~mL})$ and washed successively with $\mathrm{HCl}(100 \mathrm{~mL}, 5 \%)$, saturated $\mathrm{NaHCO}_{3}$ solution $(100 \mathrm{~mL})$, dried over anhydrous $\mathrm{Na}_{2} \mathrm{SO}_{4}$, filtered and the filtrate concentrated in vacuum to afford almost pure diester. Further purification was done by chromatography over silica gel by eluting with $20 \%$ ethyl acetate in hexane, to give $20(2.0 \mathrm{~g}, 41 \%)$ as a colorless oil; ${ }^{1} \mathrm{H}$ NMR $\left(\mathrm{CDCl}_{3}\right) \delta 3.60-3.72(\mathrm{~m}, 8 \mathrm{H}), 5.31$ (quintet, $\left.J=5.0 \mathrm{~Hz}, 2 \mathrm{H}\right), 7.60-7.63(\mathrm{~m}, 2 \mathrm{H}), 7.78-7.81(\mathrm{~m}$, $2 \mathrm{H}) ;{ }^{13} \mathrm{C} \mathrm{NMR}\left(\mathrm{CDCl}_{3}\right) \delta 50.6,72.0,128.9,131.0,131.8,166.2$. Anal. Calcd for $\mathrm{C}_{14} \mathrm{H}_{14} \mathrm{~N}_{12} \mathrm{O}_{4}$ : C, 40.58; H, 3.41; N, 40.56. Found: C, 40.80; H, 3.37; N, 40.58.

Bis[2-azido-1-(azidomethyl)ethyl] terephthalate (21). A solution of 19 (3.3 $\mathrm{mmol}_{\text {) }}$ and $\mathrm{Et}_{3} \mathrm{~N}$ $(0.45 \mathrm{~g})$ in freshly distilled ether was treated dropwise with a solution of terephthaloyl dichloride $(0.31 \mathrm{~g} 1.9 \mathrm{mmol})$ in freshly distilled ether $(10 \mathrm{~mL})$ at $0{ }^{\circ} \mathrm{C}$ for $1 \mathrm{~h}$. The solvent was evaporated under reduced pressure, and residue was recrystallized from ethyl acetate to give $21(0.55 \mathrm{~g}$, $70 \%$ ) as white crystals; mp 93-95 ${ }^{\circ} \mathrm{C} ;{ }^{1} \mathrm{H}$ NMR (DMSO- $\left.d_{6}\right) \delta 3.66-3.82(\mathrm{~m}, 8 \mathrm{H}), 5.41-5.46(\mathrm{~m}$, $2 \mathrm{H}), 8.20(\mathrm{~s}, 4 \mathrm{H}) ;{ }^{13} \mathrm{C} \mathrm{NMR}\left(\mathrm{DMSO}-d_{6}\right) \delta 50.7,72.4,129.8,133.3,164.2$. HRMS calcd for $\mathrm{C}_{14} \mathrm{H}_{14} \mathrm{~N}_{12} \mathrm{O}_{4} \mathrm{Na}[\mathrm{M}+\mathrm{Na}]^{+} 437.1153$, found: 437.1152 .

General method for the preparation of dipropiolate (23). A solution of polyethylene glycol, (E 300-900) (16 mmol), propiolic acid (2.25 g, $32 \mathrm{mmol}$ ) and $p$-toluenesulfonic acid (0.15 g, 0.8 $\mathrm{mmol})$ in toluene $(100 \mathrm{~mL})$ was heated under reflux in a Dean stark apparatus for $24-48 \mathrm{~h}$. The reaction mixture was cooled to room temperature and the solvent was removed under reduced pressure. The residue was dissolved in chloroform, washed with $\mathrm{NaHCO}_{3}(2 \times 20 \mathrm{~mL})$, water $(30$ $\mathrm{mL})$ and brine $(20 \mathrm{~mL})$. The chloroform layer was dried over anhydrous $\mathrm{MgSO}_{4}$. Filtration and evaporation of the solvent gave the corresponding dipropiolate 23a-c.

19-Oxo-3,6,9,12,15,18-hexaoxa-20-henicosyn-1-yl propiolate (23a). (mixture, see structure in Scheme 7) (98\%) Yellow oil; ${ }^{1} \mathrm{H}$ NMR $\left(\mathrm{CDCl}_{3}\right) \delta 2.95-2.98(\mathrm{~m}, 2 \mathrm{H}), 3.66$ (br s, 16H), 3.72-3.76 
(m, Hz, 4H), 4.33-4.36 (m, 4H); ${ }^{13} \mathrm{C} \mathrm{NMR}\left(\mathrm{CDCl}_{3}\right) \delta 65.3,68.6,70.6,70.7,70.8,74.6,75.5$, 152.8. Anal. Calcd for $\mathrm{C}_{18} \mathrm{H}_{26} \mathrm{O}_{9}$ : C, 55.95; H, 6.80. Found: C, 55.86; H, 6.96.

40-Oxо-3,6,9,12,15,18,21,24,27,30,33,36,39-tridecaoxa-41-dotetracontyn-1-yl propiolate (23b). (mixture, see structure in Scheme 7) (99\%) Yellow oil; ${ }^{1} \mathrm{H}$ NMR $\left(\mathrm{CDCl}_{3}\right) \delta 2.99(\mathrm{~s}, 2 \mathrm{H})$, 3.65-3.66 (m, 44H), 3.72-3.76 (m, 4H), 4.33-4.36 (m, 4H); ${ }^{13} \mathrm{C} \mathrm{NMR}\left(\mathrm{CDCl}_{3}\right) \delta$ 65.3, 68.7, 70.4, 70.6, 70.7, 70.8, 72.7, 74.6, 75.6, 152.8. Anal. Calcd for $\mathrm{C}_{32} \mathrm{H}_{54} \mathrm{O}_{16}$ : C, 55.32; H, 7.83. Found: C, 54.99; H, 8.24.

\section{1-Oxo-3,6,9,12,15,18,21,24,27,30,33,36,39,42,45,48,51,54,57,60-eicosaoxa-62-}

trihexacontyn-1-yl propiolate (23c). (mixture, see structure in Scheme 7) (98\%) Yellow semisolid; ${ }^{1} \mathrm{H}$ NMR $\left(\mathrm{CDCl}_{3}\right) \delta 3.02$ (br s, 2H), 3.64-3.66 (m, 72H), 3.72-3.76 (m, 4H), 4.33$4.36(\mathrm{~m}, 4 \mathrm{H}) ;{ }^{13} \mathrm{C} \mathrm{NMR}\left(\mathrm{CDCl}_{3}\right) \delta 65.3,68.6,70.6,70.7,70.8,74.6,75.6,77.4,152.8$. Anal. Calcd for $\mathrm{C}_{46} \mathrm{H}_{82} \mathrm{O}_{23}$ : C, 55.08; H, 8.24. Found: C, 54.63; $\mathrm{H}, 8.50$.

Ethyl 4-[4-(4-ethoxy-1-hydroxy-4-oxo-2-butynyl)phenyl]-4-hydroxy-2-butynoate (24). To a solution of ethyl propiolate $(2.5 \mathrm{~mL}, 24 \mathrm{mmol})$ in THF $(100 \mathrm{~mL})$ cooled to $-78{ }^{\circ} \mathrm{C}$ under nitrogen atmosphere was added $n$-BuLi $(15.2 \mathrm{~mL}, 1.6 \mathrm{M}$ in hexane, $24 \mathrm{mmol})$ dropwise with stirring. After $45 \mathrm{~min}$, a solution of terephthaldicarboxaldehyde $(1.07 \mathrm{~g}, 8 \mathrm{mmol})$ in THF $(40 \mathrm{~mL})$ was added dropwise. The reaction mixture was stirred for $8 \mathrm{~h}$ at $-78{ }^{\circ} \mathrm{C}$, then quenched with acetic acid $(4 \mathrm{~mL})$. The reaction mixture was allowed to warm to room temperature, water $(20 \mathrm{~mL})$ was added and the organic layer was separated. The aqueous layer was extracted with ether $(3 \times 20 \mathrm{~mL})$. The combined organic layer was dried over anhydrous $\mathrm{MgSO}_{4}$. Filtration and evaporation of the solvent gave a residue which was purified by column chromatography (silica gel) with hexane/ethyl acetate (7:3) to afford $24(2.25 \mathrm{~g}, 85 \%)$ as a yellow oil; ${ }^{1} \mathrm{H} \mathrm{NMR}\left(\mathrm{CDCl}_{3}\right)$ $\delta 1.30(\mathrm{t}, J=7.1 \mathrm{~Hz}, 6 \mathrm{H}), 3.63(\mathrm{br} \mathrm{s}, 2 \mathrm{H}), 4.24(\mathrm{q}, J=7.1 \mathrm{~Hz}, 4 \mathrm{H}), 5.54(\mathrm{~s}, 2 \mathrm{H}), 7.47(\mathrm{~s}, 4 \mathrm{H}) ;{ }^{13} \mathrm{C}$ NMR $\left(\mathrm{CDCl}_{3}\right) \delta 14.1,62.7,63.9,78.1,86.3,127.3,139.4,153.7$. Anal. Calcd for $\mathrm{C}_{18} \mathrm{H}_{18} \mathrm{O}_{6}$ : C, 65.45; H, 5.49. Found: C, 65.05; H, 5.59.

1-(1H-1,2,3-benzotriazol-1-yl)-2-propyn-1-one (26a). (61\%) Pale yellow needles (from ethyl acetate/hexane); mp $98{ }^{\circ} \mathrm{C}$ (lit. $\left.{ }^{11} \mathrm{mp} 99-100{ }^{\circ} \mathrm{C}\right){ }^{1} \mathrm{H} \mathrm{NMR}\left(\mathrm{CDCl}_{3}\right) \delta 3.70(\mathrm{~s}, 1 \mathrm{H}), 7.56(\mathrm{t}, J=7.2$ $\mathrm{Hz}, 1 \mathrm{H}), 7.71(\mathrm{t}, J=7.2 \mathrm{~Hz}, 1 \mathrm{H}), 8.16(\mathrm{~d}, J=8.1 \mathrm{~Hz}, 1 \mathrm{H}), 8.25(\mathrm{~d}, J=8.1 \mathrm{~Hz}, 1 \mathrm{H}) ;{ }^{13} \mathrm{C}$ NMR $\left(\mathrm{CDCl}_{3}\right) \delta 74.8,84.1,114.3,120.7,127.2,130.9,131.1,146.5,149.5$.

1-(1H-1,2,3-benzotriazol-1-yl)-3-phenyl-2-propyn-1-one (26b). (86\%) White needles (from ethyl acetate/hexane); mp $123-124{ }^{\circ} \mathrm{C}$ (lit. $\left.{ }^{11} \mathrm{mp} 124-125{ }^{\circ} \mathrm{C}\right){ }^{1} \mathrm{H}$ NMR $\left(\mathrm{CDCl}_{3}\right) \delta$ 7.44-7.49 (m, 2H), 7.53-7.58 (m, 2H), 7.68-7.73 (m, 1H), 7.79-7.82 (m, 2H), $8.17(\mathrm{~d}, J=8.4 \mathrm{~Hz}, 1 \mathrm{H}), 8.32$ (d, $J=8.1 \mathrm{~Hz}, 1 \mathrm{H}) ;{ }^{13} \mathrm{C} \mathrm{NMR}\left(\mathrm{CDCl}_{3}\right) \delta 81.2,96.0,114.3,119.0,120.4,126.6,128.7,130.6,130.9$, $131.7,133.6,146.3,150.4$.

2,4,6-Tris[2-(trimethylsilyl)ethynyl]-1,3,5-triazine (27). Ethynyl(trimethyl)silane (6 mL, 40 mmol) was dissolved in diethyl ether $(20 \mathrm{~mL})$ and cooled to $-78{ }^{\circ} \mathrm{C}$. Then $n$-BuLi $(1.6 \mathrm{M}$ in hexane, $25 \mathrm{~mL}, 40 \mathrm{mmol}$ ) was added dropwise with stirring. After $2 \mathrm{~h}$, all the solvents were removed under vacuum at $-10{ }^{\circ} \mathrm{C}$. To the residue, hexane $(70 \mathrm{~mL})$ was added at $-78{ }^{\circ} \mathrm{C}$. A solution of cyanuric fluoride $(1.35 \mathrm{~g}, 10 \mathrm{mmol})$ in hexane $(10 \mathrm{~mL})$ was added dropwise with stirring. After $24 \mathrm{~h}$, the reaction was allowed to reach to room temperature and stirred for a 
further $24 \mathrm{~h}$. The reaction mixture was added to water. The organic layer was separated and the aqueous layer was extracted with hexane $(3 \times 70 \mathrm{~mL})$. The combined organic layer was dried over anhydrous $\mathrm{Na}_{2} \mathrm{SO}_{4}$. It was filtered and the solvent was evaporated under vacuum to obtain 27 (1.85 g, 50\%) as brown microcrystals; mp $155-157{ }^{\circ} \mathrm{C}\left(\right.$ lit. $\left.{ }^{12} \mathrm{mp} 160{ }^{\circ} \mathrm{C}\right) ;{ }^{1} \mathrm{H} \mathrm{NMR}\left(\mathrm{CDCl}_{3}\right) \delta$ $0.28(\mathrm{~s}, 27 \mathrm{H}) ;{ }^{13} \mathrm{C} \mathrm{NMR}\left(\mathrm{CDCl}_{3}\right) \delta-0.8,100.0,102.2,159.7$.

3-Phenyl- $N$-\{8-[(3-phenyl-2-propynoyl)amino]octyl\}-2-propynamide (28). A solution of 1(1H-1,2,3-benzotriazol-1-yl)-3-phenyl-2-propyn-1-one $\mathbf{2 6 b}$ (1.24 g, $4.7 \mathrm{mmol})$ and 1,8diaminooctane $(0.36 \mathrm{~g}, 2.5 \mathrm{mmol})$ in $\mathrm{CH}_{2} \mathrm{Cl}_{2}(10 \mathrm{~mL})$ was stirred at room temperature for $12 \mathrm{~h}$. Solvent was removed under reduced pressure and the residue was washed with ether and recrystallized from ethyl acetate to give $28(0.83 \mathrm{~g}, 88 \%)$ as white crystals; mp $137-138{ }^{\circ} \mathrm{C} ;{ }^{1} \mathrm{H}$ NMR $\left(\mathrm{CDCl}_{3}\right) \delta 1.34-1.41(\mathrm{~m}, 8 \mathrm{H}), 1.55-1.60(\mathrm{~m}, 4 \mathrm{H}), 3.35(\mathrm{q}, J=6.9 \mathrm{~Hz}, 4 \mathrm{H}), 5.96(\mathrm{br} \mathrm{s}, 2 \mathrm{H})$, 7.32-7.44 (m, 6H), 7.51-7.54 (m, 4H); ${ }^{13} \mathrm{C} \mathrm{NMR}\left(\mathrm{CDCl}_{3}\right) \delta 26.7,29.0,29.2,39.9,83.1,84.5$, 120.3, 128.5, 130.0, 132.5, 154.0. Anal. Calcd for $\mathrm{C}_{26} \mathrm{H}_{28} \mathrm{~N}_{2} \mathrm{O}_{2}$ : C, 77.97; H, 7.05; N, 6.99. Found: C, 77.48; H, 7.13; N, 7.09.

General method for the preparation of bistriazoles (29-31). A mixture of dipropiolate 23 (1 mmol) and benzyl azide $(0.33 \mathrm{~g}, 2.5 \mathrm{mmol})$ was heated at $50-60{ }^{\circ} \mathrm{C}$ for $2-4 \mathrm{~h}$. The reaction mixture was cooled and washed several times with hexane to obtain the corresponding bistriazole compound (29-31).

19-(1-Benzyl-1H-1,2,3-triazol-4-yl)-19-oxo-3,6,9,12,15,18-hexaoxanonadec-1-yl 1-benzyl$\mathbf{1 H}$-1,2,3-triazole-4-carboxylate (29). (mixture of regioisomers in 1:3 ratio, 63\%) Colorless oil; ${ }^{1} \mathrm{H}$ NMR $\left(\mathrm{CDCl}_{3}\right) \delta$ 3.59-3.64 (m, 20.8H), 3.74-3.81 (m, 5.2H), 4.41-4.49 (m, 5.2H), $5.58(\mathrm{~s}, 4$ $\mathrm{H}), 5.91(\mathrm{~s}, 1.2 \mathrm{H}), 7.28-7.32(\mathrm{~m}, 7.8 \mathrm{H}), 7.38-7.40(\mathrm{~m}, 5.2 \mathrm{H}), 8.01(\mathrm{~s}, 2 \mathrm{H}), 8.17(\mathrm{~s}, 0.6 \mathrm{H}) ;{ }^{13} \mathrm{C}$ NMR $\left(\mathrm{CDCl}_{3}\right) \delta 53.6,54.6,64.3,64.8,68.8,69.1,70.7,70.7,70.8,127.7,128.2,128.4,128.6$, $128.9,129.3,129.5,133.9,135.1,138.6,140.3,158.4,160.7$. Anal. Calcd for $\mathrm{C}_{32} \mathrm{H}_{40} \mathrm{~N}_{6} \mathrm{O}_{9}$ : C, 58.89; H, 6.18; N, 12.88. Found: C, 58.75; H, 6.15; N, 13.17.

\section{0-(1-Benzyl-1H-1,2,3-triazol-4-yl)-40-oxo-3,6,9,12,15,18,21,24,27,30,33,36,39-}

tridecaoxatetracont-1-yl 1-benzyl-1H-1,2,3-triazole-4-carboxylate (30). (mixture of regioisomers in 1:4 ratio, 90\%) Yellow oil; ${ }^{1} \mathrm{H} \mathrm{NMR}\left(\mathrm{CDCl}_{3}\right) \delta 3.62-3.66(\mathrm{~m}, 55 \mathrm{H}), 3.74-3.82$ $(\mathrm{m}, 5 \mathrm{H}), 4.42-4.50(\mathrm{~m}, 5 \mathrm{H}), 5.58(\mathrm{~s}, 4 \mathrm{H}), 5.92(\mathrm{~s}, 1 \mathrm{H}), 7.28-7.32(\mathrm{~m}, 7.5 \mathrm{H}), 7.39-7.40(\mathrm{~m}, 5 \mathrm{H})$, $8.01(\mathrm{~s}, 2 \mathrm{H}), 8.17(\mathrm{~s}, 0.5 \mathrm{H}) ;{ }^{13} \mathrm{C} \mathrm{NMR}\left(\mathrm{CDCl}_{3}\right) \delta 54.6,64.3,69.1,70.7,127.7,128.2,128.4$, 128.9, 129.3, 129.5, 133.9, 140.4, 160.7. Anal. Calcd for $\mathrm{C}_{46} \mathrm{H}_{68} \mathrm{~N}_{6} \mathrm{O}_{16}: \mathrm{C}, 57.49 ; \mathrm{H}, 7.13 ; \mathrm{N}$, 8.74. Found: C, 57.33; H, 7.53; N, 7.96.

61-(1-Benzyl-1H-1,2,3-triazol-4-yl)-61-oxo-3,6,9,12,15,18,21,24,27,30,33,36,39,42,45,48,51, 54,57,60-eicosaoxahenhexacont-1-yl 1-benzyl-1H-1,2,3-triazole-4-carboxylate (31). (mixture of regioisomers in 1:4 ratio, 79\%) Yellow oil; ${ }^{1} \mathrm{H}$ NMR $\left(\mathrm{CDCl}_{3}\right) \delta 3.62-3.64(\mathrm{~m}, 90 \mathrm{H}), 3.74-$ $3.82(\mathrm{~m}, 5 \mathrm{H}), 4.42-4.50(\mathrm{~m}, 5 \mathrm{H}), 5.58(\mathrm{~s}, 4 \mathrm{H}), 5.92(\mathrm{~s}, 1 \mathrm{H}), 7.28-7.32(\mathrm{~m}, 7.5 \mathrm{H}), 7.39-7.40(\mathrm{~m}$, $5 \mathrm{H}), 8.01(\mathrm{~s}, 2 \mathrm{H}), 8.17(\mathrm{~s}, 0.5 \mathrm{H}) ;{ }^{13} \mathrm{C} \mathrm{NMR}\left(\mathrm{CDCl}_{3}\right) \delta 54.6,64.3,68.8,69.1,70.7,127.7,128.2$, 128.4, 128.9, 129.3, 129.5, 133.9, 140.3, 160.7. Anal. Calcd for $\mathrm{C}_{60} \mathrm{H}_{96} \mathrm{~N}_{6} \mathrm{O}_{23}$ : C, 56.77; H, 7.62; N, 6.62. Found: C, 56.44; H, 7.79; N, 6.35 . 
Bis\{2-[4-(ethoxycarbonyl)-1H-1,2,3-triazol-1-yl]-1-\{[4-(ethoxycarbonyl)-1H-1,2,3-triazol-1yl]methyl\}ethyl\}phthalate (33). A mixture of $20(0.41 \mathrm{~g}, 1 \mathrm{mmol})$ and ethyl propiolate 32 $(0.43 \mathrm{~g}, 4.4 \mathrm{mmol})$ was heated at $50{ }^{\circ} \mathrm{C}, 60 \mathrm{~W}$ for $1 \mathrm{~h}$ under microwave irradiation. The mixture was evaporated under reduced pressure to remove ethyl propiolate. The crude product obtained $(0.69 \mathrm{~g}$, in $85 \%)$, was purified by column chromatography to give bis $\{2$-[4-(ethoxycarbonyl)- $1 H$ 1,2,3-triazol-1-yl]-1-\{[4-(ethoxycarbonyl)-1H-1,2,3-triazol-1-yl]methyl $\}$ ethyl $\}$ phthalate 33 as the major isomer $(0.28 \mathrm{~g}, 34 \%)$ as white microcrystals, mp 97-101 ${ }^{\circ} \mathrm{C} ;{ }^{1} \mathrm{H} \mathrm{NMR}\left(\mathrm{CDCl}_{3}\right) \delta 1.37$ $(\mathrm{t}, J=6.9 \mathrm{~Hz}, 12 \mathrm{H}), 4.39$ (q, $J=6.9 \mathrm{~Hz}, 8 \mathrm{H}), 4.81(\mathrm{dd}, J=14.7,6.0 \mathrm{~Hz}, 4 \mathrm{H}), 4.96(\mathrm{dd}, J=14.7$, $4.8 \mathrm{~Hz}, 4 \mathrm{H}), 5.92-5.97(\mathrm{~m}, 2 \mathrm{H}), 7.56(\mathrm{br} \mathrm{s}, 4 \mathrm{H}), 8.45(\mathrm{~s}, 4 \mathrm{H}) ;{ }^{13} \mathrm{C} \mathrm{NMR}\left(\mathrm{CDCl}_{3}\right) \delta 14.2,50.0$, 61.4, 70.8, 129.1, 129.5, 130.2, 132.3, 140.5, 160.5, 165.8. Anal. Calcd for $\mathrm{C}_{34} \mathrm{H}_{38} \mathrm{~N}_{12} \mathrm{O}_{12}$ : C, 50.62; H, 4.75; N, 20.83. Found: C, 50.60; H, 4.73; N, 20.49.

Bis\{2-[4-(ethoxycarbonyl)-1H-1,2,3-triazol-1-yl]-1-\{[4-(ethoxycarbonyl)-1H-1,2,3-triazol-1yl]methyl\}ethyl\}terephthalate (34a). A mixture of $21(0.41 \mathrm{~g}, 1 \mathrm{mmol})$ and ethyl propiolate 32 $(0.43 \mathrm{~g}, 4.4 \mathrm{mmol})$ in toluene was heated at $50{ }^{\circ} \mathrm{C}$ for $1 \mathrm{~h}$. Ethyl propiolate was removed under vacuum to afford a semi-solid $(0.74 \mathrm{~g}, 91 \%)$ that was recrystallised from ethanol to give a white powder containing a mixture of six isomers (as indicated by TLC). After fractional recrystallization of this mixture, a major regioisomer 34a $(0.37 \mathrm{~g}, 46 \%)$ was obtained as white microcrystals (from ethanol), mp $240-243{ }^{\circ} \mathrm{C} ;{ }^{1} \mathrm{H}$ NMR (DMSO- $\left.d_{6}\right) \delta 1.22-1.29(\mathrm{~m}, 12 \mathrm{H}), 4.27$ (q, $J=7.2 \mathrm{~Hz}, 8 \mathrm{H}), 4.81-4.88(\mathrm{~m}, 4 \mathrm{H}), 5.01-5.06(\mathrm{~m}, 4 \mathrm{H}), 5.89-5.93(\mathrm{~m}, 2 \mathrm{H}), 7.91(\mathrm{~s}, 4 \mathrm{H}), 8.84$ $(\mathrm{s}, 4 \mathrm{H}) ;{ }^{13} \mathrm{C}$ NMR (DMSO-d $)_{6} \delta 14.1,50.2,60.5,71.0,129.5,130.2,132.9,138.9,160.1,163.5$. Anal. Calcd for $\mathrm{C}_{34} \mathrm{H}_{38} \mathrm{~N}_{12} \mathrm{O}_{12}$ : C, 50.62; H, 4.75; N, 20.83. Found: C, 50.88; H, 4.73; N, 20.43.

\section{1-Benzyl- $N$-(8-\{[(1-benzyl-5-phenyl-1H-1,2,3-triazol-4-yl)carbonyl]amino\}propyl)-5-}

phenyl-1H-1,2,3-triazole-4-carboxamide (35). A mixture of 3-phenyl- $N$ - $\{8$-[(3-phenyl-2propynoyl)amino]octyl $\}$-2-propynamide $28(0.60 \mathrm{~g}, 1.5 \mathrm{mmol})$ and benzyl azide $(0.44 \mathrm{~g}, 3.3$ $\mathrm{mmol})$ in benzene $(10 \mathrm{~mL})$ was heated at $80-120{ }^{\circ} \mathrm{C}$ for $72 \mathrm{~h}$. The solvent was evaporated under reduced pressure, and the residue recrystallized from ethanol to give a mixture of isomers $(0.85 \mathrm{~g}, 85 \%)$. The major regioisomer 35 was obtained $(0.46 \mathrm{~g}, 46 \%)$ as white microcrystals, $\mathrm{mp}$ 165-170 ${ }^{\circ} \mathrm{C} ;{ }^{1} \mathrm{H}$ NMR (DMSO- $\left.d_{6}\right) \delta 1.21-1.26(\mathrm{~m}, 8 \mathrm{H}), 1.40-1.45(\mathrm{~m}, 4 \mathrm{H}), 3.19-3.26(\mathrm{~m}, 4 \mathrm{H})$, $5.67(\mathrm{~s}, 4 \mathrm{H}), 6.95-6.97(\mathrm{~m}, 1 \mathrm{H}), 7.28-7.50$ (m, 17H). 7.74-7.76 (m, 3H), $8.93($ br s, $1 \mathrm{H}) ;{ }^{13} \mathrm{C}$ NMR (DMSO- $\left.d_{6}\right) \delta 26.4,28.4,28.6,52.1,126.5,127.9,128.1,128.2,128.3,128.6,128.7,128.9$, 129.9, 135.3, 143.5, 159.3. Anal. Calcd for $\mathrm{C}_{40} \mathrm{H}_{42} \mathrm{~N}_{8} \mathrm{O}_{2}$ : C, 72.05; H, 6.35; N, 16.80. Found: C, 71.99; H, 6.20; N, 16.42 .

2,4,6-Tris[1-benzyl-4-(trimethylsilyl)-1H-1,2,3-triazol-5-yl]-1,3,5-triazine (36). A mixture of $27(0.37 \mathrm{~g}, 1 \mathrm{mmol})$ and benzyl azide $(0.7 \mathrm{~g}, 5 \mathrm{mmol})$ was heated at $50-60{ }^{\circ} \mathrm{C}$ for $8 \mathrm{~h}$. The reaction mixture was washed with hexane several times and the residue was recrystallized from hexane-ethyl acetate mixture to obtain $36(45 \%)$ as light pink microcrystals, mp $236{ }^{\circ} \mathrm{C} ;{ }^{1} \mathrm{H}$ NMR $\left(\mathrm{CDCl}_{3}\right) \delta 0.07(\mathrm{~s}, 27 \mathrm{H}), 5.72(\mathrm{~s}, 6 \mathrm{H}), 6.76(\mathrm{~d}, J=7.5 \mathrm{~Hz}, 6 \mathrm{H}), 7.09(\mathrm{t}, J=7.3 \mathrm{~Hz}, 6 \mathrm{H}), 7.18(\mathrm{t}, J$ $=7.3 \mathrm{~Hz}, 3 \mathrm{H}) ;{ }^{13} \mathrm{C} \mathrm{NMR}\left(\mathrm{CDCl}_{3}\right) \delta-0.6,53.2,127.2,128.7,129.2,135.2,137.8,151.8,166.6$. Anal. Calcd for $\mathrm{C}_{39} \mathrm{H}_{48} \mathrm{~N}_{12} \mathrm{Si}_{3}$ : C, 60.90; H, 6.29; N, 21.85. Found: C, 61.12; H, 6.37; N, 22.11. 
X-Ray Crystallography. Data were collected with a Bruker ApexII CCD area detector, using graphite monochromatized MoK $\alpha$ radiation $(\lambda=0.71073 \AA)$. The intensities were corrected for Lorentz and polarization effects and for absorption. ${ }^{24}$ The structure was solved by direct methods using SHELXS ${ }^{25}$ and refined on $\mathrm{F}^{2}$, using all data, by full-matrix least-squares procedures using SHELXTL. ${ }^{26}$ All non-hydrogen atoms were refined with anisotropic displacement parameters. Hydrogen atoms were included in calculated positions, with isotropic displacement parameters 1.2 times the isotropic equivalent of their carrier carbons. Complete crystallographic data, as a CIF file, have been deposited with the Cambridge Crystallographic Data Centre (CCDC No 276346). Copies can be obtained free of charge from: The Director, CCDC, 12 Union Road, Cambridge CB2 1EZ, U.K. (e-mail: deposit@ccdc.cam.ac.uk).

Crystal data for 36. $\mathrm{C}_{39} \mathrm{H}_{48} \mathrm{~N}_{12} \mathrm{Si}_{3}$, MW 769.16, monoclinic, Cc, colorless prism, $0.30 \mathrm{x} 0.21 \mathrm{x}$ $0.19 \mathrm{~mm}, a=11.3918(3), b=20.5533(5), c=18.2086(5) \AA, \beta=98.092(1)^{\circ}, \mathrm{V}=4220.9(2) \AA^{3}$,

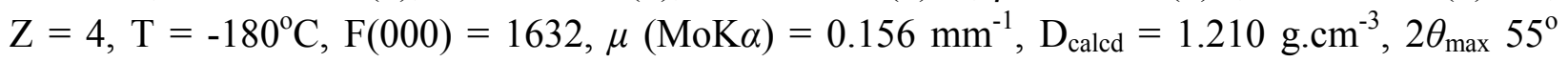
(CCD area detector, $100 \%$ completeness), $w \mathrm{R}\left(\mathrm{F}^{2}\right)=0.0728$ (all 9698 data), $\mathrm{R}=0.0287$ (9327 data with $\mathrm{I}>2 \sigma \mathrm{I})$.

\section{Acknowledgements}

We thank Dr. Clifford D. Bedford (Office of Naval Research, VA) for helpful discussions, and Jim Simpson and Lyall Hanton (University of Otago) for collection of the X-ray data. We are pleased to acknowledge the significant help that we received in preparing this manuscript from Dr. Kathy Yang and Dr. Paritosh Dave of SAIC, Picatinny, New Jersey. Specifically, the preparations of compounds 20 and 21 were based on procedures (to be published by them elsewhere) which they kindly communicated to us and which were of material assistance in our work. Financial support for this work from the Office of Naval Research (Grant Number: N00014-03-1-0121) and Strategic Environmental Research and Development Program (SERDP) under their PP-1404 Project is gratefully acknowledged. We thank Dr. D. H. Powell for providing mass spectra.

\section{References}

1. (a) Fan, W.-Q.; Katritzky, A. R. In Comprehensive Heterocyclic Chemistry; Katritzky, A. R.; Rees, C. W.; Scriven, E. F. V., Eds.; Pergamon Press: New York, 1984; Vol. 4, p 101. (b) Benson, F. R.; Savell, W. L. Chem. Rev. 1950, 1. (c) Boyer, J. H. In Heterocyclic Compounds; Elderfield, R. C., Ed.; Wiley: New York, 1961; Vol. 7, Chapter 5, p 384. (d) Gilchrist, T. L.; Gymer, G. E. In Advances in Heterocyclic Chemistry; Katritzky, A. R.; Boulton, A. J., Eds.; Academic Press: New York, 1974; Vol. 16, p 33. (e) Lwowski, W. In 1,3-Dipolar Cycloaddition Chemistry; Padwa, A., Ed.; Wiley-Interscience: New York, 
1984; Vol. 1, p 559. (f) Sha, C.-K.; Mohanakrishnan, A. K. In Chemistry of Heterocyclic Compounds; Padwa, A.; Pearson, W. H., Eds.; John Wiley: New York, 2002; Vol. 59, p 623.

2. (a) Reed, R. Jr. US Pat. 6103029, 2000; Chem. Abstr. 2000, 133, 152741. (b) Thompson, C. M.; Hergenrother, P. M. High Perform. Polym. 2001, 13, 313; Chem. Abstr. 2002, 136, 310257.

3. (a) Ykman, P.; L'Abbe, G.; Smets, G. J. Indian Chem. Soc. 1972, 49, 1245; Chem. Abstr. 1973, 79, 19154. (b) Krongauz, E. S.; Korshak, V. V.; Travnikova, A. P. Vysokomol. Soedin., Ser. B 1967, 9, 563; Chem. Abstr. 1967, 67, 100460. (c) Yuldasheva, Kh.; Dzhuraev, A. D.; Makhsumov, A. G.; Amanov, N. Khim.- Farm. Zh. 1991, 25, 52; Chem. Abstr. 1992, 116, 18278. (d) Abu-Orabi, S.; Atfah, A.; Jibril, I.; Marii, F.; Ali, A. A. S. Gazz. Chim. Ital. 1991, 121, 397; Chem. Abstr. 1992, 116, 21002. (e) Rogov, N. G.; Kabanova, E. P.; Gruzdeva, I. G. Ross. Khim. Zh. 1997, 41, 115; Chem. Abstr. 1997, 127, 206015.

4. (a) Tamura, Y.; Chun, M. W.; Kwon, S.; Bayomi, S. M.; Okada, T.; Ikeda, M. Chem. Pharm. Bull. 1978, 26, 3515. (b) Abu-Orabi, S. T.; Atfah, M. A.; Jibril, I.; Mari'i, F. M.; Ali, A. A.S. J. Heterocycl. Chem. 1989, 26, 1461. (c) Lalezari, I.; Gomez, L. A.; Khorshidi, M. J. Heterocycl. Chem. 1990, 27, 687. (d) Gouault, N.; Cupif, J.-F.; Sauleau, A.; David, M. Tetrahedron Lett. 2000, 41, 7293. (e) Katritzky, A. R.; Zhang, Y.; Singh, S. K.; Steel, P. J. ARKIVOC 2003, (xv), 47.

5. 5. (a) Gorgues, A.; Le Coq, A. Tetrahedron Lett. 1979, 4829. (b) Banert, K. Chem. Ber. 1989, 122, 123. (c) Wigerinck, P.; Aerschot, A. V.; Claes, P.; Balzarini, J.; De Clercq, E.; Herdewijn, P. J. Heterocycl. Chem. 1989, 26, 1635. (d) Buckle, D. R.; Rockell, C. J. M. J. Chem. Soc., Perkin Trans. 1 1982, 627. (e) Häbich, D.; Barth, W. Heterocycles 1989, 29, 2083. (f) Palacios, F.; Ochoa de Retana, A. M.; Pagalday, J. Heterocycles 1994, 38, 95. (g) Businelli, S.; Martino, E. D.; Zanirato, P. ARKIVOC 2001, (i), 131.

6. Ashton, P. R.; Anderson, D. W.; Brown, C. L.; Shipway, A. N.; Stoddart, J. F.; Tolley, M. S. Chem. Eur. J. 1998, 4, 781.

7. Luedtke, A. E.; Timberlake, J. W. J. Org. Chem. 1985, 50, 268.

8. Bouzide, A.; LeBerre, N.; Sauvé, G. Tetrahedron Lett. 2001, 42, 8781.

9. Achatz, O.; Grandl, A.; Wanner, K. T. Eur. J. Org. Chem. 1999, 8, 1967.

10. Vereshchagin, L. I.; Bol'shedvorskaya, R. L.; Maksikova, A. V.; Serebryakova, E. S.; Kozyrev, S. V.; Bratilov, B. I.; Proidakov, A. G. Zh. Org. Khim. 1987, 23, 2303.

11. Katritzky, A. R.; Zhang, Y.; Singh, S. K. Synthesis 2003, 2795.

12. Kouvetakis, J; Grotjahn, D.; Becker, P.; Moore, S.; Dupon, R. Chem. Mater. 1994, 6, 636.

13. Liu, P.; Chen, Y.; Deng, J.; Tu, Y. Synthesis 2001, 2078.

14. (a) Garrett, T. M.; McMurry, T. J.; Hosseini, M. W.; Reyes, Z. E.; Hahn, F. E.; Raymond, K. N. J. Am. Chem. Soc. 1991, 113, 2965. (b) Wuytswinkel, G. V.; Compernolle, F.; Toppet, S.; Dehaen, W. J. Chem. Soc., Perkin Trans. 1 2000, 1337.

15. Kidd, T. J.; Leigh, D. A.; Wilson, A. J. J. Am. Chem. Soc. 1999, 121, 1599. 
16. Ashkenazi, N.; Vigalok, A.; Parthiban, S.; Ben-David, Y.; Shimon, L. J. W.; Martin, J. M. L.; Milstein, D. J. Am. Chem. Soc. 2000, 122, 8797.

17. Chen, Y.; Baker, G. L. J. Org. Chem. 1999, 64, 6870.

18. Newcomb, M.; Moore, S. S.; Cram, D. J. J. Am. Chem. Soc. 1977, 99, 6405.

19. (a) Gansow, O. A.; Kausar, A. R.; Triplett, K. B. J. Heterocycl. Chem. 1981, 18, 297. (b) Gunzenhauser, S.; Biala, E.; Strazewski, P. Tetrahedron Lett. 1998, 39, 6277.

20. Andrus, M. B.; Turner, T. M.; Updegraff, E. P.; Sauna, Z. E.; Ambudkar, S. V. Tetrahedron Lett. 2001, 42, 3819.

21. Chen, Y.; Yang, F. Chem. Lett. 2000, 484.

22. James, N. R.; Jayakrishnan, A. J. Appl. Polym. Sci. 2003, 87, 1852.

23. Wilson, E. R.; Frankel, M. B. J. Chem. Eng. Data 1982, 27, 472.

24. Sheldrick, G. M. SADABS, University of Göttingen, Germany, 1998.

25. Sheldrick, G. M. Acta Crystallogr. Sect. A 1990, 46, 467.

26. Sheldrick, G. M. SHELXTL; Bruker Analytical X-ray Systems, 1997. 